Dear author,

Please note that changes made in the online proofing system will be added to the article before publication but are not reflected in this PDF.

We also ask that this file not be used for submitting corrections. 


\title{
Buccal dental-microwear and feeding ecology of Early Pleistocene Theropithecus oswaldi from Cueva Victoria (Spain)
}

\author{
Q12 L.M. Martínez ${ }^{\text {a, }}$, F. Estebaranz ${ }^{\text {a, b }}$, C. Ferràndez-Cañadell ${ }^{c}$, A. Romero ${ }^{d}$, F. Ribot ${ }^{e}$, \\ J. Galbany ${ }^{\text {f,g }}{ }^{\text {, L. Gibert }}{ }^{\mathrm{h}}$, A. Pérez-Pérez ${ }^{\text {a }}$ \\ ${ }^{a}$ Departament de Biologia Evolutiva, Ecologia i Ciències Ambientals, Secció de Zoologia i Antropologia Biològica, Universitat de Barcelona, Av. Diagonal 643, \\ 08014, Barcelona, Spain \\ ${ }^{\mathrm{b}}$ Departament de Biologia Animal, Biologia Vegetal i Ecologia, Unitat d'Antropologia Biològica, Universitat Autònoma de Barcelona, Campus de Bellaterra, \\ 08193, Bellaterra - Cerdanyola del Vallès, Spain \\ ${ }^{c}$ Departament Dinàmica de la Terra i de l'Oceà, Facultat de Ciències de la Terra, Universitat de Barcelona, Martí Franquès s/n, 08028, Barcelona, Spain \\ ${ }^{\mathrm{d}}$ Departamento de Biotecnología, Facultad de Ciencias, Universidad de Alicante, 99, 03080, Alicante, Spain \\ e Museo Municipal de Prehistoria y Paleontología, Calle Las Tiendas s/n, 18858, Orce, Granada, Spain \\ ${ }^{\mathrm{f}}$ Departament de Psicologia Clínica i Psicobiologia, Universitat de Barcelona, Facultat de Psicologia, Passeig de la Vall d'Hebron, 171, 08035, Barcelona, Spain \\ ${ }^{g}$ Center for the Advanced Study of Human Paleobiology, Department of Anthropology, The George Washington University, Washington DC, USA \\ h Departament de Mineralogia, Petrologia i Geologia Aplicada, Facultat de Ciències de la Terra, Universitat de Barcelona, Martí Franquès s/n, 08028, \\ Barcelona, Spain
}

\section{A R T I C L E I N F O}

\section{Article history:}

Received 13 November 2018

Accepted 20 November 2019

Available online $\mathrm{xxx}$

\section{Keywords:}

Buccal microwear

Theropithecus

Papionini

Paleoecology

Cueva Victoria

Early Pleistocene

\begin{abstract}
A B S T R A C T
Despite the scarcity of fossil specimens of Theropithecus oswaldi in Eurasia, its presence out of Africa attests to the great dispersal of this Papionini genus during the Early Pleistocene. In the present study, we analyze the buccal dental microwear of $T$. oswaldi (T. o. leakeyi) fossil specimens from Cueva Victoria (Southeastern Spain). This analysis is the first characterization of the feeding ecology of $T$. oswaldi in Europe. The buccal microwear pattern of the molar and premolar teeth of T. oswaldi from Cueva Victoria shows great similarities to that observed for the extant frugivorous forest-dwelling Mandrillus sphinx and mangabeys (Cercocebus sp.)-both species adapted to durophagous dietary habits-while significantly differed from that observed for the gramnivorous Theropithecus gelada. These results suggest that T. oswaldi from Cueva Victoria could have exploited both hard-shelled fruits or seeds and succulent fruits from open and forested Mediterranean ecosystems.
\end{abstract}

(c) 2020 Elsevier Ltd. All rights reserved.

\section{Introduction}

Theropithecus oswaldi was one of the most abundant and widely distributed African Papionini primate species during the PlioPleistocene, occurring at sites from North Algeria to South Africa (Delson et al., 1993). In Kenya, the earliest Theropithecus appearance dates to 4.1 Ma (million years ago) at Kanapoi (Cerling et al., 2013). The T. oswaldi fossils from Woranso Mille in Ethiopia represent the earliest fossils from Theropithecus in East Africa, documented as early as 3.76 Ma (Frost et al., 2014; Levin et al., 2015). In the Turkana Basin, Theropithecus brumpti is dated as early as 3.6 Ma (Jablonski et al., 2008). From these regions, Theropithecus spread throughout East Africa and migrated into South Africa at least twice, as well as

\footnotetext{
* Corresponding author.

E-mail address: Imartinez@ub.edu (L.M. Martínez).
}

out of Africa during the Pleistocene (Pickford, 1993). In the African central dispersion area of the genus, 2 partially contemporaneous lineages coexisted. The first is T. brumpti that inhabited the Lake Turkana region and has been found in the Shungura Formation, Nachukui Formation, Koobi Fora Fomations, and Tugen Hills' sequence. The second, T. oswaldi, was the most abundant primate, as well as mammal species, in the African fossil record during the Pleistocene (Delson et al., 1993; Leakey, 1993; Jablonski, 2002). The abundance of Theropithecus species, especially T. oswaldi, in eastern African deposits may be because of their occupation of habitats that were more prone to fossilization, such as the shores of lakes and rivers, as well as to their greater population numbers (Benefit and McCrossin, 1990). T. oswaldi expanded beyond the Sahara desert, showing a typical circum-Mediterranean distribution.

Cercopithecid fossil specimens attributed to T. oswaldi, or T. cf. oswaldi have also been recovered at localities outside Africa, such as 
in India (Gupta and Sahni, 1981; Delson, 1993; Pickford, 1993), Israel (Belmaker, 2010), and Spain (Gibert et al., 1995; Ferràndez-Cañadell et al., 2014). However, Eurasian Papionini primates are sparsely represented in the fossil record.

Despite the abundance of Theropithecus remains in the African Pleistocene record at $0.5 \mathrm{Ma}$, the Theropithecus lineage experienced a significant regression and almost disappeared (Elton, 2007). The simultaneous expansion to East Africa of South African Papio displaced the Theropithecus populations, probably because of the ecological flexibility of Papio in confronting abrupt climatic fluctuations during the middle to late Pleistocene, unlike Theropithecus (Jablonski, 2002; Elton, 2007). In North Africa, Theropithecus is represented by Theropithecus atlanticus (Alemseged and Geraads, 1998) during the Pliocene (Ternifine site, Algeria) and the Middle Pleistocene (Thomas Quarry site, Morocco). The extinction of T. oswaldi in Africa coincided with the onset of the Pleistocene major climatic fluctuations (Leakey, 1993; Hughes et al., 2008). At present, the unique extant representative of the genus is Theropithecus gelada, an endemic species to the Ethiopian highlands where 2 genetically distinct subspecies of geladas are found (Belay and Mori, 2006).

Outside Africa, the extinct T. oswaldi is only found in Early Pleistocene deposits, although stepping out simulations suggest that the dispersal of Theropithecus into Eurasia occurred during the Pliocene (Hughes et al., 2008). The out of Africa event for Theropithecus is documented at various sites, such as Cueva Victoria in southeast Spain (Gibert et al., 1995; Ferràndez-Cañadell et al., 2014), Ubeidiya in Israel (Belmaker, 2010), and Mizanpur in India (Gupta and Sahni, 1981; Delson, 1993; Pickford, 1993).

Despite the scarcity of Theropithecus species in Eurasian sites, their ecological behavior has been suggested to be more flexible than what might be assumed based on the ecology of $T$. gelada (Hughes et al., 2008). The fossil records of South Africa and Eurasia show that Theropithecus faced competition from existing local primate species (Papio and Parapapio in South Africa and Macaca and the colobines in Eurasia), and as a result, they never reached the high population densities observed in East Africa (Hughes et al., 2008).

\subsection{Paleoecological reconstruction of Cueva Victoria}

Cueva Victoria is a large karstic system located in southeastern Spain, consisting of more than $3 \mathrm{~km}$ of galleries (Gibert et al., 2006; Ferràndez-Cañadell, 2015a) (Fig. 1A). The site has provided remains of more than 90 species of fossil vertebrates, including a hominin phalanx, and the only undisputed specimen of the African cercopithecid T. oswaldi in Europe (Ferràndez-Cañadell and Gibert, 2015). The fossils recovered from sediments infilling the karstic cavities date to $\sim 0.9-0.85 \mathrm{Ma}$ by means of paleomagnetism, vertebrate biostratigraphy, and ${ }^{230} \mathrm{Th} / \mathrm{U}$ series (Gibert et al., 2016). The highly oxidizing conditions of the karstic sediments prevented the preservation of plant remains in Cueva Victoria, including pollen. Two independent attempts at pollen analyses from coprolites from hyenas (Pachycrocuta) and large herbivores were unsuccessful (Carrión et al., 2007; Ferràndez-Cañadell, 2015b). The interpretation of the vegetation near the cave is thus based on the paleocological data from the vertebrate assemblage (Gibert et al., 1992; Ferràndez-Cañadell, 2015a, b; Gibert and Ferràndez-Cañadell, 2015).

The extensive faunal assemblage found at Cueva Victoria, including both autochthonous and parautochthonous species, is composed of 6 amphibian species, 8 squamates, 1 turtle, 44 birds, and 43 mammals. Cueva Victoria was a hyena's den; the large mammal remains were probably carried into the cave by Pachycrocuta from a wide hunting area of tens of square kilometres $\left(\mathrm{km}^{2}\right)$ along the Mediterranean coastline, representing different biomes in the region surrounding the site (Ferràndez-Cañadell, 2015a). The herbivores include browsers, such as Mammuthus or Megaloceros, and grazers, such as Equus or Hemitragus, as well as mixed feeders or opportunistic species, such as Dama or Stephanorhinus etruscus. The equids include a large horse, Equus suessenbornensis, adapted to open and dry habitats, and a smaller one, Equus altidens, adapted to closed and wet areas, such as savanna-mosaic woodlands (Alberdi and Piñero, 2015). The largest felids found in the cave, Homotherium and Megantereon, might have been adapted to forested habitats (Brugal and Croitor, 2007; Palmqvist et al., 2003, 2011), although Homotherium has been described as a pursuit predator adapted to relatively open environments with some vegetation cover (Anton et al., 2005; Madurell-Malapeira et al., 2014). The faunal association suggests a Mediterranean climate, with temperate winter temperatures. The landscape also included open areas with short pastures and with sparsely wooded areas of mature forest. Nearby bodies of water are indicated by the presence of large, obligate drinker herbivores, such as Mammuthus or Stephanorhinus (Palmqvist et al., 2003), also indicated by $\delta^{18} \mathrm{O}$ analyses (Palmqvist et al., 2011) and the presence of the bats Rhinolophus hipposideros and Myotis nattereri (Sevilla, 2015).

\subsection{Dietary ecology of Theropithecus}

Theropithecus shows significant morphological and ecological diversity, likely related to shifts in environmental conditions during the Plio-Pleistocene in both East and South Africa. The evolutionary radiation of the Cercopithecoidea (Papio, Cercopithecus, and Theropithecus) after $1.75 \mathrm{Ma}$ in South Africa coincided with the expansion of open habitats in this region. The co-occurrence in the fossil record of several terrestrial papionins is consistent with niche partitioning (Elton, 2007) and distinct dietary adaptations among species (El-Zaatari et al., 2005; Codron et al., 2005).

Theropithecus oswaldi probably exploited arboreal substrates in a manner similar to some modern baboons (Elton, 2002), whereas the East African Theropithecus would have occupied more terrestrial niches (Jolly, 1972:; Krentz, 1993). However, the postcranial traits of T. brumpti from East Africa indicate a mix of adaptations to arboreal and terrestrial locomotion (Ciochon, 1993; Elton, 2002).

Carbon 13 isotope analyses indicate that $T$. oswaldi had a diet primarily based on $\mathrm{C}_{4}$ grasses (Lee-Thorpe et al., 1989; Lee-Thorpe and van der Merwe, 1993; Van Der Merwe et al., 2003; Cerling et al., 2013; Levin et al., 2015), similar to the graminivorous dietary regimen of the extant geladas. However, T. oswaldi from Swartkrans shows a distinct isotopic signature suggestive of $20 \%-40 \% C_{3}$ plant consumption, with greater ingestion of fruits in comparison to the extant geladas (Benefit and McCrossin, 1990). Codron et al. (2005) also found variable isotopic signals in T. oswaldi ranging from $60 \%$ to $100 \%$ of grass content in their diet. The variable intake of $C_{3}$ foods would indicate a mixed diet in the extinct forms, with a more generalist regime than their modern counterparts (Codron et al., 2005). Out of Africa, the isotopic signal for the 1 Ma Indian fossil specimen of Theropithecus delsoni (Patnaik and Nanda, 2010) is consistent with a primarily $\mathrm{C}_{4}$ diet in a highly seasonal ecosystem, whereas the dental microwear dietary signature supports a grazing dietary regimen (Patnaik et al., 2014). As a whole, the carbon 13 isotopic dietary proxy shows a shift from a mixed $C_{3} / C_{4}$ diet to a major $C_{4}$ dietary component along the evolutionary lineage of Theropithecus (Souron, 2018). Before $3 \mathrm{Ma}$, the diets of the fossil Theropithecus species ( $T$. brumpti and T. oswaldi) comprised both $\mathrm{C}_{3}$ (up to 65\%) and $\mathrm{C}_{4}$ plant foods (Cerling et al., 2013; Levin et al., 2015; Wynn et al., 2016; Souron, 2018). The $C_{3}$ resources could consist of herbaceous plants (forbs and graminoids) present in 

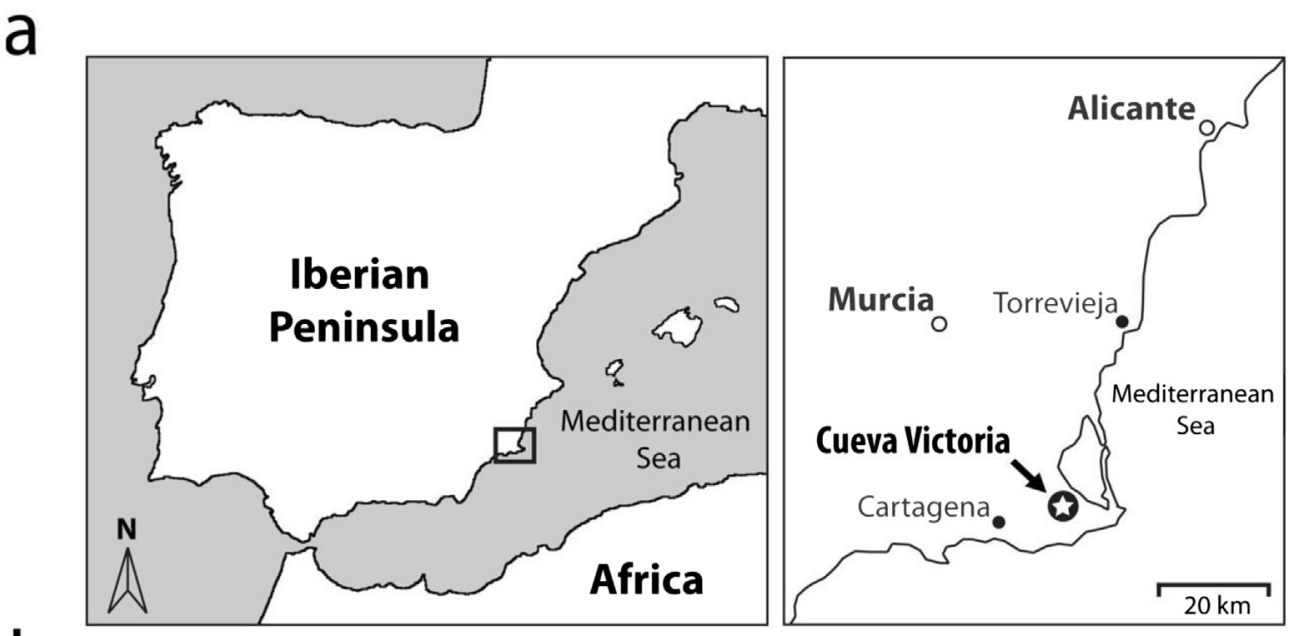

b
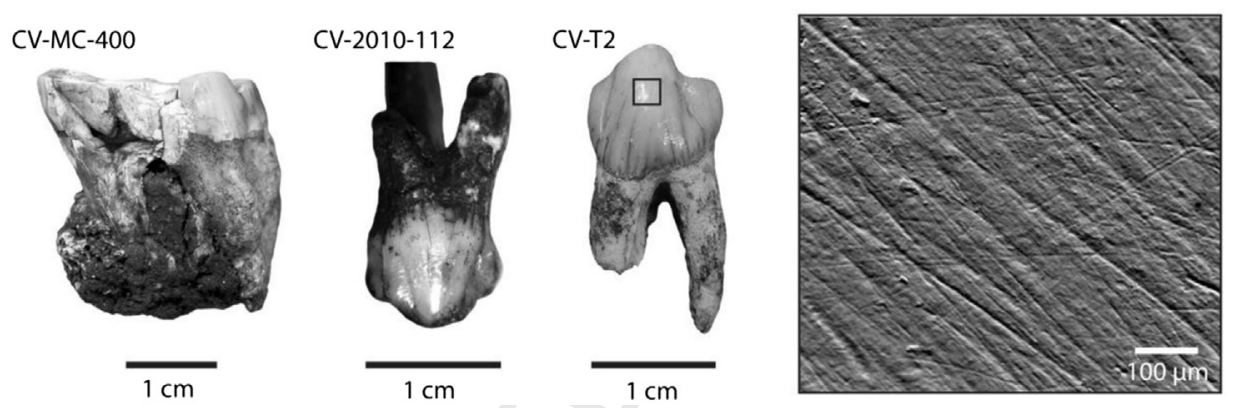

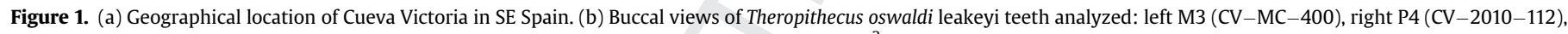
and left P4 (CV-T2). The micrograph represents a well-preserved buccal enamel area of $0.56 \mathrm{~mm}^{2}$ at $100 \times$ from CV-T2 (see black square).

African lowland habitats during the Plio-Pleistocene (Bonnefille. 2010; Albert et al., 2015; Magill et al., 2016).

Levin et al. (2014) have suggested that the consumption of $C_{4}$ food resources by the earliest members of $T$. oswaldi could have preceded the anatomical dental specialization for grazing, which occurred after a full terrestrial adaptation was acquired, allowing the exploitation of a great diversity of food resources. All members of Theropithecus exhibit expanded, high-crowned, bilophodont molars, and high cusp reliefs with curved infoldings of enamel between dentine zones when worn (Jablonski, 1993a; b), which suggest that gramnivory was a primitive dietary condition for the genus. The extant $T$. gelada has traditionally been considered an obligate gramnivore (Dunbar and Bose, 1991; Jablonski, 1994; Swedell, 2011; Cerling et al., 2013), though this characterization was based on studies in disturbed ecosystems (Souron, 2018). A recent, multiyear study at Guassa Plateau-an intact, tall-grass ecosystem in the Ethiopian Central Highlands-has expanded the documented diversity of gelada diets (Fashing et al., 2014). The T. gelada from Guassa feed more heavily on forbs and invertebrates and less heavily on graminoids (57\% of annual diet). Moreover, during the dry season, $T$. gelada relies much less intensively on underground storage organs than individuals from disturbed sites (Fashing et al., 2014; Venkataraman et al., 2014). Shapiro et al. (2016) showed that geladas at Guassa had more complex and heterogeneous microwear textures on occlusal dental enamel surfaces than geladas from other sites, which indicates of a wide range of diets and feeding ecological adaptations in the Guassa geladas (Fashing et al., 2014; Shapiro et al., 2016). This distinct dietary habit might relate to differences in forb and graminoid consumption (Shapiro et al., 2016). Previous studies at Guassa have also suggested that $T$. gelada specimens prefer food items with high dry matter and less water content, suggesting that water scarcity is not a serious issue for geladas in the highlands where evapotranspiration is high (Moges and Balakrishnan, 2014). Iwamoto and Dunbar (1983) suggested similar dietary habits for the extant T. gelada from Gich, in the Ethiopian Simien Mountains. The geladas from undisturbed sites are highly selective feeders, consuming a variety of herbaceous vegetation, including large quantities of graminoids and forbs, whereas during the dry season, they mainly rely on nutritive and tender forbs (Shapiro et al., 2016) with a significantly higher dietary diversity than during the wet seasons (Woldegeorgis and Bekele, 2015).

Occlusal dental microwear patterns of fossil Theropithecus specimens (Teaford, 1993) have shown similar size and frequency of pit and scratches in both $T$. oswaldi and $T$. gelada that could be because of similar, although not identical, dietary regimes. However, T. brumpti showed a higher pitting incidence in comparison to T. oswaldi and T. gelada, suggesting a diet containing more fruit or gritty contaminants for $T$. brumpti. Occlusal microwear studies by El-Zaatari et al. (2005) found no differences in microwear signatures (occlusal enamel pits and scratches) between $T$. oswaldi from South Africa and T. gelada and placed T. oswaldi within the dietary categories of modern Colobus guereza, suggesting a more varied diet than in modern geladas, including grasses and/or leaves, in addition to fruits. In fact, Shapiro et al. (2016) showed no differences in occlusal dental microwear textures between $T$. gelada from Guassa and the fossil T. oswaldi. Overall, occlusal microwear pattern analyses support the mix fruit-folivorous diet for the fossil specimens (Benefit and McCrossin, 1990).

The aim of the present study is to characterize the feeding ecology of T. oswaldi leakeyi from Cueva Victoria based on buccal dental microwear analysis. Microscopic-scale buccal tooth wear is 
highly correlated with the physical properties of foods ingested because no tooth-to-tooth contact occurs during enamel scratching without pitting incidence (Pérez-Pérez et al., 2003; Romero et al., 2012, 2013). Buccal dental microwear of molar and premolar teeth has been shown to reflect the physical properties of chewed foodstuffs and long-term trends in dietary preferences (Galbany et al., 2005a; Estebaranz et al., 2012; Romero et al., 2012, 2013). During food chewing, striations of different length and orientations are formed across buccal enamel surfaces. Particles that are harder than enamel, such as plant phytoliths and grit or dust incorporated during food processing, can scratch buccal enamel surfaces

Q4.5 (Lalueza-Fox et al., 1994; Lucas et al., 2008, 2013; Gügel et al., 2001; Romero et al., 2012, 2013). Thus, the type and amount of chewed abrasives, their intrinsic hardness compared with enamel, as well as the crystallite structure of dental enamel, are critical in the formation of microwear enamel features (Gügel et al., 2001; Lucas et al., 2008, 2013; Romero et al., 2012, 2013; Xia et al., 2017. Early reports on buccal microwear of extant Cercopithecoidea primates have shown a clear relationship between the hardness of foodstuffs and specific buccal-microwear patterns (Galbany et al., 2005a; Estebaranz et al., 2009, 2012; Martínez et al., 2016). However, to date, no information exists about diet-related buccal-microwear signatures from European Theropithecus specimens. The present research provides independent and relevant evidence on the dietary adaptations of this Eurasia group considering the scarcity of Theropithecus remains out of Africa.

\section{Material and methods}

\subsection{The fossil specimens and the extant comparative samples}

We studied 4 teeth of $T$. oswaldi recovered from deposits in Cueva Victoria (Gibert et al., 1995; Ferràndez-Cañadell et al., 2014) curated at the Departament de Dinàmica de la Terra i de l'Oceà of the University of Barcelona. The studied teeth $(n=4)$ correspond to a lower left $\mathrm{P}_{4}$ (CV-T2), an upper right $\mathrm{P}^{4}(\mathrm{CV}-2010-112)$, a partial lower left $\mathrm{M}_{3}$ (CV-MC-400), and a partial lower or upper molar (CV2011-591). The teeth were fully described in Ferràndez-Cañadell et al. (2014) and showed well-preserved enamel surfaces suitable for buccal-microwear analyses (Fig. 1B). The T. oswaldi teeth from Cueva Victoria were found at different locations inside the cave. The 2 molars were dug in situ, close to one another, in a systematic excavation using a scaffold attached to the walls of the cave, $8.0 \mathrm{~m}$ above the base of the fossiliferous breccia and $1.5 \mathrm{~m}$ below the flowstone where the magnetic reversal occurs (Cañadell et al., 2014). The 2 premolars were found in fossiliferous sediments reworked by the mining activity at different locations inside the cave (T2 and CM). An additional unerupted lower right $\mathrm{M}_{2}(\mathrm{CV}-1)$ was recovered in 1990 in a different location inside the main room (Sala Union). Based on their distinct wear stages, the 2 premolars (left $\mathrm{P}_{4}$ and right $\mathrm{P}^{4}$ ) would belong to different individuals (Ferràndez-Cañadell et al., 2014). The association of CV-MC-400, the worn left $\mathrm{M}_{3}$, and the worn upper premolar is possible. Consequently, a minimum of 2 individuals can be estimated. However, the hypothesis that the worn upper premolar and the worn lower third molar belonged to different individuals cannot be entirely ruled out (Ferràndez-Cañadell et al., 2014). Therefore, our final sample consists of 3 teeth (CV-MC-400, CV-2010-112, and CV$\mathrm{T} 2)$ belonging to a minimal number of 2 individuals $(\mathrm{NMI}=2$ ). Specimen CV-2011-591 was discarded from the microwear analysis because a reliable identification of the buccal side of the molar fragment could not be done.

Buccal microwear data of Cercopithecoidea primates were available for comparative purposes (Galbany et al., 2005a; Estebaranz et al., 2009, 2012; Martínez et al., 2016). The comparative sample $(\mathrm{n}=97$ ) belonged to 7 Cercopithecoidea taxa and was obtained from the Anthropological Institute and Museum of Zurich University (Mandrillus sphinx, Cercocebus sp.); the Harvard Museum of Comparative Zoology, the American Museum of Natural History and the Field Museum, in Chicago (T. gelada); and National Museum of Kenya osteological collections (Papio sp., Colobus sp., Chlorocebus sp., Cercopithecus sp.). Specimens of the same taxa were chosen, whenever possible, from close localities to minimize the variability regime of their diet. For instance, $T$. gelada specimens came from the Ethiopian highlands, Papio anubis specimens came from Kenyan localities (Ewaso N'giro, Laikipia and Baringo); M. sphinx specimens came from Gabon, Equatorial Guinea, and Cameroon; Cercocebus species came from Liberia (Cercocebus atys), Tana River (Cercocebus galeritus), Congo and Gabon (Cercocebus torquatus); Chlorocebus pygerythrus came from Kenyan localities (Kibwezi, Masaai Mara, Naivasha, and Tigoni); Cercopithecus mitis came from Kenyan localities (Kinangop, Tigoni, and Kipkabus); and Colobus species came from Uganda, Kenya, and Liberia. This comparative sample served to establish a broad spectrum of ecological and dietary diversity and includes preferably second lower or upper molars, when available, and second premolars.

1. Theropithecus gelada (geladas, $\mathrm{n}=8$ ) specimens from the Ethiopia Highlands were included as the only extant primate species of the genus. The dietary regime of $T$. gelada is specialized in the exploitation of a gramnivorous niche (Dunbar and Bose, 1991) with more than $80 \%$ of their diet made up of grass blades (Mau et al., 2009). Although food preference may differ across localities, the diversity of eaten items remains constant among populations (Zewdu et al., 2013), with slight variations in dietary composition between the dry and wet season (Mau et al., 2009; Moges and Balakrishnan, 2014) and with occasional consumption of insects (Fashing et al., 2010).

2. Mandrillus sphinx (mandrills, $\mathrm{n}=7$ ) lives in equatorial rainforests and in gallery forests adjacent to savannas, as well as rocky forests, riparian forests, cultivated areas, and flooded forests and streambeds. Fruits constitute the mandrill's major dietary item, supplemented with various plant parts and insects (Lahm, 1986). Forest dwelling mandrills mostly feed (over 70\% year-round) on mechanically protected plant foods, such as hard-shell fruits or seeds from the forest floor. They also climb trees to eat leaves, lianas, bark, stems, and fibers (Hoshino, 1985; Lahm, 1986).

3. Cercocebus sp. $(\mathrm{n}=9)$ included the species $C$. galeritus, $C$. atys, and $C$. torquatus. Cercocebus species share craniodental adaptations for feeding on tough-skinned fruit and on hard nuts and seeds (Kay, 1981; Fleagle and McGraw, 2002; Singleton, 2005). The mangabeys show a fallback feeding strategy, eating barks or seeds when preferred foods (fruits) are unavailable (Daegling et al., 2011; McGraw et al., 2012). The Tana crested mangabey (C. galeritus) inhabits the seasonal riverine forest on the Tana River in Kenya and is an omnivore primate that generally forages at the lower canopy (Homewood, 1978), following a generalist flexible feeding strategy (Wieczkowski and Kinnaird, 2008). Their annual diet consists in fruits and seeds (Wieczkowski, 2003), although during the dry season, they rely on dry hard seeds that they pick from the ground (Wieczkowski, 2009). Collared mangabeys (C. torquatus) live in coastal, swamp mangrove, and valley forests, and their diet is mainly based on fruits (60\%) and seeds (20\%) but also eats leaves, foliage, flowers, invertebrates, mushrooms, dung, and gum (Mitani, 1989). C. atys, the West African sooty mangabey, is a terrestrial forager that habitually feeds on hard Sacoglottis nuts year-round, with seasonal fluctuations in which the nut comprises $25-80 \%$ of the 
monthly diet (Daegling et al., 2011). C. atys and C. galeritus are similar in its durophagous habits (Wieczkowski, 2009).

4. P. anubis (olive baboon, $\mathrm{n}=27$ ) is usually considered a savannadwelling species living in the wide grassland plains, especially those near open woodlands, but it also inhabits rainforests and deserts. $P$. anubis is a generalist feeder, and its diet typically includes a large variety of plants, invertebrates, and small mammals, as well as birds. Olive baboons eat leaves, grass, roots, bark, flowers, fruits, lichens, tubers, seeds, and mushrooms, as well as corms and rhizomes that are especially important during droughts (Whiten et al., 1991).

5. Ch. pygerythrus (vervet monkey, $\mathrm{n}=15$ ) inhabits savanna woodlands. Its feeding ecology consists mostly of fruits, seeds, and flowers, also including leaves and small mammals and insects (Lee, 1984; Willems and Hill, 2009).

6. Cercopithecus mitis (blue monkey, $n=10$ ) is found in evergreen forests and lives largely in the forest canopy, rarely descending to the ground, in humid, shady areas with plenty of water. They are primarily frugivorous, with $50 \%$ of their diet consisting of fruits, with leaves or insects as their main source of protein. They eat a variety of plants but concentrate on a few species (Pazol and Cords, 2005).

7. The colobus monkey (Colobus sp.) sample $(\mathrm{n}=21)$ included Colobus angolensis, Colobus badius, C. guereza, and Colobus polykomos. They all are arboreal, traditionally classified as genuine leaf-eaters (Oates and Davies, 1994) but are considered to have a heterogeneous diet, also including fruits, flowers, and twigs (Dasilva, 1994). Colobus monkeys live in a wide range of habitats, including primary and secondary forests, riverine forests, and wooded grasslands. Their ruminant-like digestive systems have enabled these leaf-eaters to occupy niches that are inaccessible to other primates (McGraw et al., 2016).

\subsection{Buccal dental microwear analysis}

The dental crowns of the fossil specimens of $T$. oswaldi from Cueva Victoria were cleaned with ethanol, using a cotton ear-bud to remove dust and grease and were left to air dry. Molds were prepared with President Microsystem regular body polyvinylsiloxane (Colténe ${ }^{\mathrm{TM}}$ ), following conventional procedures (Galbany et al., 2006). The impression material, which shows excellent dimensional stability and reproduction of microscopic detail (Galbany et al., 2006), was applied from the occlusal border to the tooth roots, including the cemento-enamel junction and from the mesial to the distal borders (Galbany et al., 2006). Tooth replicas were obtained from the original molds using a two-base component, high-resolution polyurethane (Feropur PR + E55; Feroca ${ }^{\circledR}$ Composites, Spain). The polyurethane was stirred and poured into the molds using a Pasteur pipette. Molds were then centrifuged for $1 \mathrm{~min}$ at $1000 \mathrm{rpm}$ to remove air bubbles from buccal enamel surfaces. Finally, the positive dental replicas were mounted on aluminum stubs, sputter-coated with 20 Å gold layer and stored in a dust-free cupboard before scanning electron microscopy (SEM) analysis. Before SEM digitization, all the casts were examined at $40 \times$ with a stereomicroscope to determine their suitability for microwear analysis. The buccal enamel surface of each tooth crown was placed perpendicular to the electron beam, with the occlusal crown rim facing upward in all SEM images parallel to the cement-enamel junction on the buccal surface. The digital images were taken in the middle third of the crown, avoiding both the occlusal and cervical thirds of the buccal crown surface, at $100 \times$ magnification, 18-25 mm working distance, and $15 \mathrm{kV}$ acceleration voltage, based on previous standard protocols (Galbany et al., 2006; Romero et al., 2012). All the micrographs were captured at the SEM facilities at the SS. TT. de Investigación of the Universidad de Alicante. SEM images were cropped to exactly cover $0.56 \mathrm{~mm}^{2}$ $(748.33 \times 748.33 \mu \mathrm{m})$ of buccal enamel surface, and a high-pass (50-pixel) filter and the automatic grey levels adjustment in Photoshop CS6 (Adobe ${ }^{\mathrm{TM}}$ ) were applied to all cropped digital grey-scale images to reduce shadows and enhance image contrast, following standard procedures in buccal dental microwear research (PérezPérez et al., 2003; Galbany et al., 2005a; Estebaranz et al., 2009, 2012; Romero et al., 2012, 2013; Martínez et al., 2016). Finally, individual lineal enamel striations were counted, and their length (in micrometers, $\mu \mathrm{m}$ ) and slope (relative to the cemento-enamel junction) were semiautomatically measured using the Sigma Scan ProV (SPSSTM v.15) package.

The buccal microwear patterns of the several extant cercopithecid primate samples were available from the literature (Galbany et al., 2005a; Estebaranz et al., 2012; Martínez et al., 2016). The extant geladas, C. atys, M. sphinx, and the fossil T. oswaldi teeth were measured by LMM, following the same standardized procedures. Interobserver error had been previously quantified and found to be less than $4 \%$ among experienced researchers (Galbany et al., 2005b). Striations, the only microwear signature present on buccal enamel surfaces, were recorded as linear marks on the enamel surface at least 4 times longer than its width (4:1 ratio) and with a minimum length of $15 \mu \mathrm{m}$, regardless of curvature (PérezPérez et al., 2003), including those that were truncated by the edge of the micrographs (Teaford and Walker, 1984; Pérez-Pérez et al., 2003; Romero et al., 2012). The buccal microwear variables analyzed include the number $(\mathrm{N})$ and average length $(\mathrm{X})$ of the total observed lineal striations $(\mathrm{T})$ per individual tooth. Striations were classified into $45^{\circ}$ orientation intervals (from $0^{\circ}$ to $180^{\circ}$ ) as follows: horizontal $(\mathrm{H})$, vertical $(\mathrm{V})$, mesio-distal $(\mathrm{MD})$, and disto-mesial (DM). Thus, a total of 10 variables ( $\mathrm{N}$ and $\mathrm{X}$ for $\mathrm{T}$ as well as for $\mathrm{H}$, $\mathrm{V}, \mathrm{MD}$, and DM orientations) were derived for the sample studied, which characterize the buccal dental microwear pattern (PérezPérez et al., 2003; Galbany et al., 2005a).

Owing to the reduced sizes of some extant primates samples and that 2 variables ( $\mathrm{NH}$ and NDM) did not pass the Levene's Test of homoscedasticity ( $p$-value $<0.05$ ), all the variables were ranktransformed and parametric analyses were carried out (Romero et al., 2013). A single-classification multivariate and univariate analyses of variance were performed on the microwear data to test the sources of significant variation. In addition, pairwise differences between taxa were tested using the Tukey's honestly significant difference (HSD) post-hoc test. Finally, a canonical variate analysis (CVA) was conducted with the density (NH, NV, NMD, and NDM) and length $(\mathrm{XH}, \mathrm{XV}, \mathrm{XMD}$, and $\mathrm{XDM}$ ) derived buccal-microwear variables to test the feeding ecological inferences of $T$. oswaldi with those reported for the 7 extant African Cercopithecoidea taxa (Martínez et al., 2016). The NT and XT variables were not included in the CVA because their high collinearity levels with other variables (Romero et al., 2013). Descriptive statistics and tests were

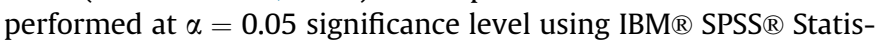
tics 19.0 and Addinsoft ${ }^{\mathrm{TM}}$ XLSTAT-3.02 statistical packages.

\section{Results}

The descriptive buccal dental-microwear statistics (mean and standard deviation of the 10 microwear variables) for the individual taxa are shown in Table 1 . The multivariate analysis of variance including T. oswaldi indicated significant differences (Wilks' $\lambda$; $F=3.572, p<0.0001$ ) in buccal dental-microwear signatures between taxa (Table 2). The individual analysis of variance identified 8 variables showing significant differences between taxa $(\mathrm{p}<0.05)$, including the striation densities (NH, NV, NMD, NDM, and NT) and the vertical $(\mathrm{XV})$ and horizontal $(\mathrm{XH})$ striation lengths, and the total 
Table 1

Summary statistics (mean and standard deviation; SD) of the buccal dental microwear variables for all the taxa analyzed.

\begin{tabular}{|c|c|c|c|c|c|c|c|c|c|}
\hline Variable & & P. anubis & C. mitis & Ch.pygerythrus & T.gelada & Cercocebus sp. & Colobus sp. & M. sphinx & T.oswaldi \\
\hline \multirow[t]{2}{*}{$\mathrm{NH}^{\mathrm{a}}$} & Mean & 21.44 & 34.80 & 34.67 & 23.38 & 55.33 & 42.48 & 40.29 & 45.00 \\
\hline & $\mathrm{SD}$ & 9.14 & 21.50 & 19.38 & 19.73 & 32.16 & 28.50 & 17.56 & 22.61 \\
\hline \multirow[t]{2}{*}{$\mathrm{NV}^{\mathrm{a}}$} & Mean & 85.81 & 108.80 & 81.00 & 77.88 & 43.00 & 35.57 & 59.14 & 44.00 \\
\hline & SD & 26.07 & 14.99 & 25.46 & 29.12 & 28.71 & 18.16 & 17.03 & 28.62 \\
\hline \multirow[t]{2}{*}{$\mathrm{NMD}^{\mathrm{a}}$} & Mean & 49.78 & 60.60 & 56.40 & 42.00 & 71.44 & 37.05 & 60.86 & 136.67 \\
\hline & SD & 25.05 & 25.71 & 24.85 & 35.76 & 42.10 & 21.89 & 49.29 & 69.41 \\
\hline \multirow[t]{2}{*}{$\mathrm{NDM}^{\mathrm{a}}$} & Mean & 20.44 & 39.80 & 38.53 & 37.38 & 69.78 & 30.62 & 75.86 & 67.67 \\
\hline & SD & 15.69 & 20.75 & 15.38 & 19.66 & 35.81 & 18.36 & 37.05 & 52.54 \\
\hline \multirow[t]{2}{*}{$\mathrm{XH}^{\mathrm{b}}$} & Mean & 90.78 & 83.88 & 73.22 & 68.76 & 83.56 & 79.41 & 60.78 & 68.76 \\
\hline & SD & 22.52 & 31.81 & 15.80 & 24.70 & 19.15 & 17.17 & 18.66 & 15.54 \\
\hline \multirow[t]{2}{*}{$\mathrm{XV}^{\mathrm{b}}$} & Mean & 118.28 & 99.82 & 112.13 & 122.50 & 86.91 & 112.22 & 100.18 & 97.13 \\
\hline & SD & 18.26 & 18.41 & 20.95 & 24.32 & 26.83 & 31.31 & 19.99 & 32.97 \\
\hline \multirow[t]{2}{*}{$\mathrm{XMD}^{\mathrm{b}}$} & Mean & 88.79 & 74.37 & 75.22 & 84.49 & 70.07 & 74.91 & 67.15 & 68.69 \\
\hline & SD & 19.28 & 19.36 & 12.09 & 25.99 & 23.95 & 24.47 & 24.32 & 41.03 \\
\hline \multirow[t]{2}{*}{$\mathrm{XDM}^{\mathrm{b}}$} & Mean & 86.25 & 76.01 & 80.93 & 81.70 & 67.09 & 85.26 & 63.57 & 108.04 \\
\hline & SD & 21.74 & 21.49 & 18.25 & 27.50 & 18.72 & 29.29 & 18.86 & 49.44 \\
\hline \multirow[t]{2}{*}{$\mathrm{NT}^{\mathrm{a}}$} & Mean & 177.48 & 244.00 & 210.60 & 180.63 & 239.56 & 145.71 & 236.14 & 293.33 \\
\hline & SD & 34.32 & 44.85 & 38.36 & 66.93 & 84.08 & 34.37 & 40.05 & 20.50 \\
\hline \multirow[t]{2}{*}{$\mathrm{XT}^{\mathrm{b}}$} & Mean & 103.73 & 87.36 & 90.32 & 97.26 & 76.79 & 89.40 & 74.10 & 72.70 \\
\hline & SD & 14.29 & 18.36 & 9.76 & 17.61 & 13.82 & 16.92 & 16.38 & 19.14 \\
\hline
\end{tabular}

a Striation densities (NH, NV, NMD, NDM and NT) in micrometers $(\mu \mathrm{m})$.

b Striation length variables $(\mathrm{XH}, \mathrm{XV}, \mathrm{XDM}, \mathrm{XMD}, \mathrm{XT})$ in micrometers $(\mu \mathrm{m})$. See Material and methods section for further details on sample and variable names.

Table 2

MANOVA and ANOVA results testing differences in buccal-microwear patterns.

\begin{tabular}{lccc}
\hline MANOVA & Test statistic & $\mathrm{F}$ & $\mathrm{p}^{a}$ \\
\hline Wilks' $\lambda$ & 0.091 & 3.572 & $\mathbf{0 . 0 0 0}$ \\
Pillai trace & 1.746 & 2.958 & $\mathbf{0 . 0 0 0}$ \\
Hotelling-Lawley & 3.554 & 4.128 & $\mathbf{0 . 0 0 0}$ \\
\hline ANOVAs & Mean square & $\mathrm{F}_{7,85}$ & $\mathrm{p}$ \\
\hline NH & 2576.719 & 3.634 & $\mathbf{0 . 0 0 1}$ \\
NV & 6360.184 & 15.085 & $\mathbf{0 . 0 0 0}$ \\
NMD & 2362.782 & 3.256 & $\mathbf{0 . 0 0 4}$ \\
NDM & 4167.593 & 7.088 & $\mathbf{0 . 0 0 0}$ \\
XH & 1930.354 & 2.543 & $\mathbf{0 . 0 1 9}$ \\
XV & 1783.083 & 2.315 & $\mathbf{0 . 0 3 2}$ \\
XMD & 1534.599 & 1.945 & 0.071 \\
XDM & 1381.769 & 1.726 & 0.112 \\
NT & 5415.636 & 10.973 & $\mathbf{0 . 0 0 0}$ \\
XT & 3630.368 & 5.767 & $\mathbf{0 . 0 0 0}$ \\
\hline
\end{tabular}

a Significance of p-values in bold correspond to $\alpha<0.05$

average striation length (XT). No significant among-taxa differences were found for the oblique (XMD and XDM) striation lengths. Tukey's honesty post-hoc test (HSD) showed that $T$. oswaldi significantly differed $(\mathrm{p}<0.05)$ from the extant comparative primate taxa for 4 (NV, NMD, NT, and XT) of the 10 buccal-microwear variables analyzed (Table 3). The pairwise comparisons showed that $T$. oswaldi $(\mathrm{NT}=255.67)$ exhibits more abraded buccal enamel surfaces than the leaf-eater Colobus sp. $(\mathrm{NT}=145.71), T$. gelada $(\mathrm{NT}=180.63$ ), and Papio anubis (NT = 177.48) specimens (Fig. 2). C. mitis (NT $=244.00)$ significantly differed in NT from Colobus sp., T. gelada, and P. anubis. M. sphinx $(\mathrm{NT}=236.14)$ also showed a higher buccal enamel striation density than colobines and $P$. anubis. The lower striation density in the colobines contrasts with those from the hard-object feeder Cercocebus sp. $(\mathrm{NT}=239.56)$ and the frugivorous $C$. mitis and Ch. pygerythrus $(\mathrm{NT}=210.60)$ species.

The buccal-microwear densities further differentiated species with distinct mechanical food demands, such as the folivorous colobines that exhibited significantly lower NV values than the grass eater T. gelada and savanna-generalist feeder $P$. anubis, as well as than the fruit eaters, such as Ch. pygerythrus and $C$. mitis, that showed significant higher NV values than Cercocebus sp., M. sphinx, and T. oswaldi. The fossil Theropithecus differs from Colobus sp. in having significant higher NMD values. The low NDM values in P. anubis significantly differ from the higher values found in C. mitis, Ch. pygerythrus, Cercocebus sp, and M. sphinx. Regarding the length variables, Tukey's HSD test showed that $P$. anubis $(\mathrm{XT}=103.73 \mu \mathrm{m})$ had significantly longer average striation length (XT) values than those found in Colobus sp. $(\mathrm{XT}=89.40 \mu \mathrm{m})$, C. mitis $(\mathrm{XT}=87.36 \mu \mathrm{m})$, Cercocebus sp. $(\mathrm{XT}=76.79 \mu \mathrm{m})$, M. sphinx $(\mathrm{XT}=74.10 \mu \mathrm{m})$, and T. oswaldi $(\mathrm{XT}=72.70 \mu \mathrm{m}$ ) that showing the smallest value (Fig. 2). Overall, the taxa examined exhibited significant overlapping in striation length ranges for most orientations categories, and only $P$. anubis showed longer horizontal striations $(\mathrm{XH})$ than M. sphinx and longer vertical striations (XV) than Cercocebus species (Table 3 ).

A CVA was performed with 8 buccal-microwear variables considered (NH, NV, NMD, NDM, XH, XV, XMD, and XDM). The CVA, including the extant African Cercopithecoidea primates and the extinct T. oswaldi species, yielded 7 discriminant functions that accounting for the $100 \%$ of total variance (Wilks' $\lambda=0.127 ; \mathrm{p}<0.0001$ ). The posterior correct classification probability (Table 5 ) was $69 \%$ of the entire whole sample (56\% correct classification after leave-oneout cross validation; Table 6). The first 2 canonical variates (CV1-2) explained $84.304 \%$ of total variance (Table 4, Fig. 3). CV1 (51.812\%) exhibited a strong significant positive correlation (Pearson $r$ ) with the density of vertical striations (NV: $r=0.922 ; \mathrm{p}<0.001$ ). CV1 was also significantly correlated with $\mathrm{NH}(r=-0.409 ; \mathrm{p}<0.001)$, NDM $(r=-0.301 ; \mathrm{p}=0.002)$, and $\mathrm{XMD}(r=0.325 ; \mathrm{p}=0.001)$. Altogether, only the densities of horizontal (NH) and disto-mesial (NDM) striations loaded negatively onto CV1, whereas NV, NMD, and all the length variables loaded positively. The first canonical variate (CV1) discriminated taxa with specialized, mechanically demanding diets, such as hard-fruit eaters (Mandrillus and Cercocebus) and leaf eaters (Colobus sp), from the rest of the extant primates studied. The frugivorous (C. mitis and Ch. pygerythrus), gramnivorous (T. gelada), and savanna forager (P. anubis) species showed positive CV1 values, whereas the leaf-eaters Colobus specimens, Mandrillus, and Cercocebus specimens showed the most negative values for CV1, indicative of relatively more horizontal than vertical striations. The second canonical variate (CV2) explained $32.491 \%$ of total variance and was significantly correlated mainly with $\operatorname{NDM}(r=0.762 ; \mathrm{p}<0.001)$, thus reflecting the density of the disto-occlusal to mesio-cervical striations-those mostly produced by abrasive particles moving from distal to mesial (back to front) and from occlusal to cervical in the 
Table 3

Multiple paired comparison post-hoc tests (matrices of pairwise mean differences) between taxa.

\begin{tabular}{|c|c|c|c|c|c|c|c|c|c|c|c|c|c|c|c|c|}
\hline NH & & P.anubis & $\mathrm{Cm}$ & $C p$ & $\mathrm{Tg}$ & $\mathrm{Cer}$ & $\mathrm{Col}$ & Ms & XH & P.anubis & $\mathrm{Cm}$ & $C p$ & $\mathrm{Tg}$ & $\mathrm{Cer}$ & $\mathrm{Col}$ & Ms \\
\hline C. mitis & $\mathrm{Cm}$ & -19.226 & & & & & & & $\mathrm{Cm}$ & 13.729 & & & & & & \\
\hline Ch.pygerythrus & $C p$ & -21.092 & -1.866 & & & & & & $C p$ & 22.363 & 8.633 & & & & & \\
\hline T.gelada & $\mathrm{Tg}$ & 0.011 & 19.237 & 21.104 & & & & & $\mathrm{Tg}$ & 29.379 & 15.650 & 7.016 & & & & \\
\hline Cercocebus sp. & Cer & $-38.148^{a}$ & -18.922 & -17.055 & -38.159 & & & & $\mathrm{Cer}$ & 8.518 & -5.211 & -13.844 & -20.861 & & & \\
\hline Colobus sp. & $\mathrm{Col}$ & $-24.664^{\mathrm{a}}$ & -5.438 & -3.571 & -24.675 & 13.484 & & & $\mathrm{Col}$ & 12.772 & -0.957 & -9.590 & -16.607 & 4.253 & & \\
\hline M. sphinx & Ms & -31.211 & -11.985 & -10.119 & -31.223 & 6.936 & -6.547 & & Ms & 38.344 & 24.614 & 15.980 & 8.964 & 29.825 & 25.571 & \\
\hline T.oswaldi & To & -34.759 & -15.533 & -13.666 & -34.770 & 3.388 & -10.095 & -3.547 & To & 30.629 & 16.900 & 8.266 & 1.250 & 22.111 & 17.857 & -7.714 \\
\hline NV & & P.anubis & $\mathrm{Cm}$ & $C p$ & $\mathrm{Tg}$ & $\mathrm{Cer}$ & $\mathrm{Col}$ & Ms & XV & P.anubis & $\mathrm{Cm}$ & $C p$ & $\mathrm{Tg}$ & $\mathrm{Cer}$ & Col & Ms \\
\hline C. mitis & $\mathrm{Cm}$ & -20.001 & & & & & & & $\mathrm{Cm}$ & 23.650 & & & & & & \\
\hline Ch.pygerythrus & $C p$ & 4.648 & 24.650 & & & & & & $C p$ & 8.466 & -15.183 & & & & & \\
\hline T.gelada & $\mathrm{Tg}$ & 7.210 & 27.212 & 2.562 & & & & & $\mathrm{Tg}$ & -4.375 & -28.025 & -12.841 & & & & \\
\hline Cercocebus sp. & Cer & $37.203^{a}$ & $57.205^{\mathrm{a}}$ & $32.555^{a}$ & 29.993 & & & & $\mathrm{Cer}$ & $33.333^{\mathrm{a}}$ & 9.683 & 24.866 & 37.708 & & & \\
\hline Colobus sp. & $\mathrm{Col}$ & $44.053^{\mathrm{a}}$ & $64.054^{\mathrm{a}}$ & $39.404^{\mathrm{a}}$ & $36.842^{\mathrm{a}}$ & 6.849 & & & $\mathrm{Col}$ & 9.785 & -13.864 & 1.319 & 14.160 & -23.547 & & \\
\hline M. sphinx & Ms & 24.005 & $44.007^{a}$ & 19.357 & 16.794 & -13.198 & -20.047 & & Ms & 21.000 & -2.650 & 12.533 & 25.375 & -12.333 & 11.214 & \\
\hline T.oswaldi & To & 36.481 & $56.483^{a}$ & 31.833 & 29.270 & -0.722 & -7.571 & 12.476 & To & 23.000 & -0.650 & 14.533 & 27.375 & -10.333 & 13.214 & 2.000 \\
\hline NMD & & P.anubis & $\mathrm{Cm}$ & $C p$ & $\mathrm{Tg}$ & $\mathrm{Cer}$ & Col & Ms & XMD & P.anubis & $\mathrm{Cm}$ & $C p$ & $\mathrm{Tg}$ & $\mathrm{Cer}$ & $\mathrm{Col}$ & Ms \\
\hline C. mitis & $\mathrm{Cm}$ & -13.300 & & & & & & & $\mathrm{Cm}$ & 18.422 & & & & & & \\
\hline Ch.pygerythrus & $C p$ & -8.366 & 4.933 & & & & & & $C p$ & 16.422 & -2.000 & & & & & \\
\hline T.gelada & $\mathrm{Tg}$ & 12.875 & 26.175 & 21.241 & & & & & $\mathrm{Tg}$ & 7.409 & -11.012 & -9.012 & & & & \\
\hline Cercocebus sp. & Cer & -17.444 & -4.144 & -9.077 & -30.319 & & & & $\mathrm{Cer}$ & 27.888 & 9.466 & 11.466 & 20.479 & & & \\
\hline Colobus sp. & Col & 14.523 & 27.823 & 22.890 & 1.648 & 31.968 & & & $\mathrm{Col}$ & 21.579 & 3.157 & 5.157 & 14.169 & -6.309 & & \\
\hline M. sphinx & Ms & -2.142 & 11.157 & 6.223 & -15.017 & 15.301 & -16.666 & & Ms & 26.936 & 8.513 & 10.513 & 19.526 & -0.952 & 5.357 & \\
\hline T.oswaldi & To & -42.500 & -29.200 & -34.133 & -55.375 & -25.055 & $-57.023^{\mathrm{a}}$ & -40.357 & To & 29.888 & 11.466 & 13.466 & 22.479 & 2.000 & 8.309 & 2.952 \\
\hline NDM & & P.anubis & $\mathrm{Cm}$ & $C p$ & $\mathrm{Tg}$ & $\mathrm{Cer}$ & $\mathrm{Col}$ & Ms & XDM & P.anubis & $\mathrm{Cm}$ & $C p$ & $\mathrm{Tg}$ & $\mathrm{Cer}$ & $\mathrm{Col}$ & Ms \\
\hline C. mitis & $\mathrm{Cm}$ & $-28.331^{\mathrm{a}}$ & & & & & & & $\mathrm{Cm}$ & 15.240 & & & & & & \\
\hline Ch.pygerythrus & $C p$ & $-26.848^{\mathrm{a}}$ & 1.483 & & & & & & $C p$ & 4.940 & -10.300 & & & & & \\
\hline T.gelada & $\mathrm{Tg}$ & -24.793 & 3.537 & 2.054 & & & & & $\mathrm{Tg}$ & 4.865 & -10.375 & -0.075 & & & & \\
\hline Cercocebus sp. & Cer & $-48.981^{\mathrm{a}}$ & -20.650 & -22.133 & -24.187 & & & & Cer & 21.962 & 6.722 & 17.022 & 17.097 & & & \\
\hline Colobus sp. & Col & -15.529 & 12.802 & 11.319 & 9.264 & $33.452^{\mathrm{a}}$ & & & $\mathrm{Col}$ & 3.740 & -11.500 & -1.200 & -1.125 & -18.222 & & \\
\hline M. sphinx & Ms & $-52.767^{\mathrm{a}}$ & -24.435 & -25.919 & -27.973 & -3.785 & $-37.238^{\mathrm{a}}$ & & Ms & 31.455 & 16.214 & 26.514 & 26.589 & 9.492 & 27.714 & \\
\hline T.oswaldi & To & -42.481 & -14.150 & -15.633 & -17.687 & 6.500 & -26.952 & 10.285 & To & -12.592 & -27.833 & -17.533 & -17.458 & -34.555 & -16.333 & -44.047 \\
\hline NT & & P.anubis & $\mathrm{Cm}$ & $C p$ & $\mathrm{Tg}$ & $\mathrm{Cer}$ & $\mathrm{Col}$ & Ms & XT & P.anubis & $\mathrm{Cm}$ & $C p$ & $\mathrm{Tg}$ & $\mathrm{Cer}$ & Col & Ms \\
\hline C. mitis & $\mathrm{Cm}$ & $-34.451^{\mathrm{a}}$ & & & & & & & $\mathrm{Cm}$ & $29.246^{a}$ & & & & & & \\
\hline Ch.pygerythrus & $C p$ & -19.751 & 14.700 & & & & & & $C p$ & 22.562 & -6.683 & & & & & \\
\hline T.gelada & $\mathrm{Tg}$ & 0.835 & $35.287^{a}$ & 20.587 & & & & & $\mathrm{Tg}$ & 13.983 & -15.262 & -8.579 & & & & \\
\hline Cercocebus sp. & Cer & -26.018 & 8.433 & -6.266 & -26.854 & & & & Cer & $45.462^{\mathrm{a}}$ & 16.216 & 22.900 & 31.479 & & & \\
\hline Colobus sp. & $\mathrm{Col}$ & 17.386 & $51.838^{\mathrm{a}}$ & $37.138^{\mathrm{a}}$ & 16.550 & $43.404^{\mathrm{a}}$ & & & $\mathrm{Col}$ & $24.129^{a}$ & -5.116 & 1.566 & 10.145 & -21.333 & & \\
\hline M. sphinx & Ms & $-31.709^{a}$ & 2.742 & -11.957 & -32.544 & -5.690 & $-49.095^{\mathrm{a}}$ & & Ms & $46.796^{a}$ & 17.550 & 24.233 & 32.812 & 1.333 & 22.666 & \\
\hline T.oswaldi & To & $-53.351^{\mathrm{a}}$ & -18.900 & -33.600 & $-54.187^{a}$ & -27.333 & $-70.738^{\mathrm{a}}$ & -21.642 & To & $47.796^{\mathrm{a}}$ & 18.550 & 25.233 & 33.812 & 2.333 & 23.666 & 1.000 \\
\hline
\end{tabular}

a Significance of $\mathrm{p}$-values in bold correspond to $\alpha<0.05$.

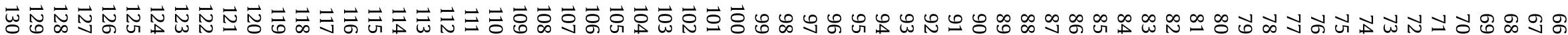



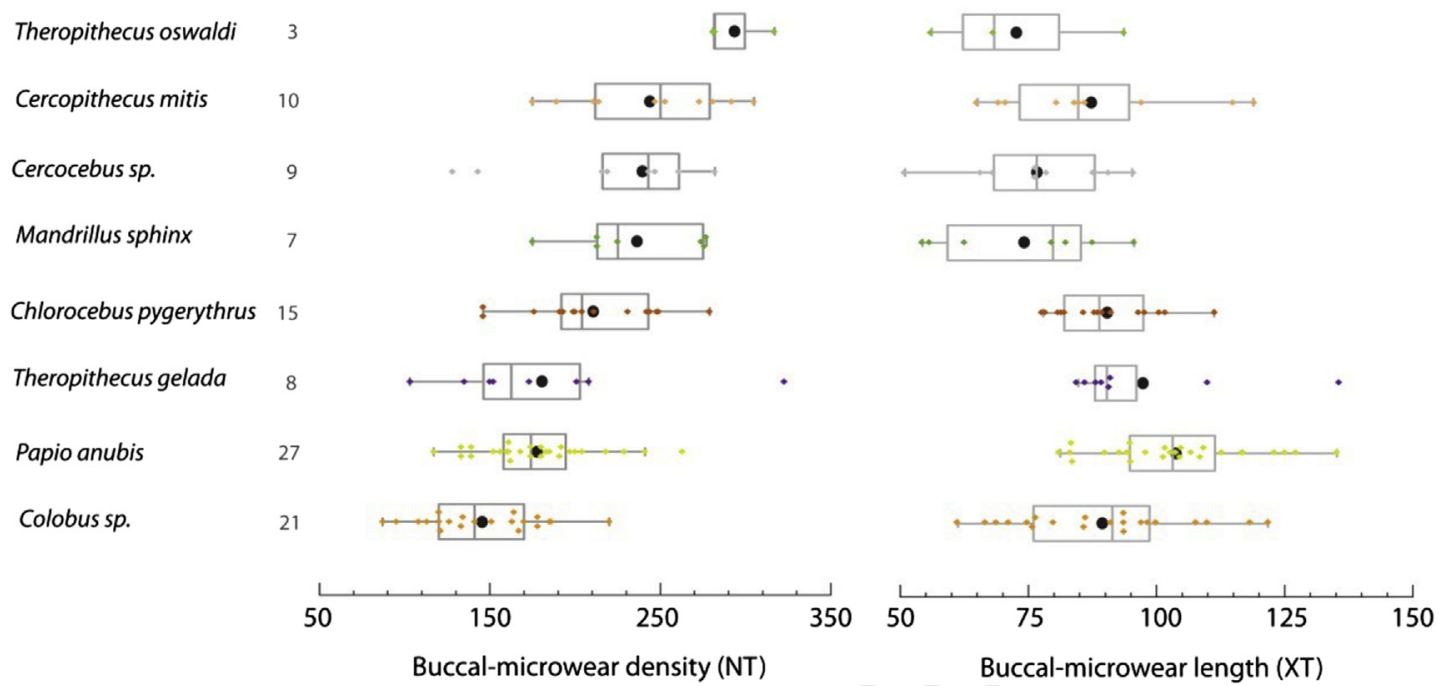

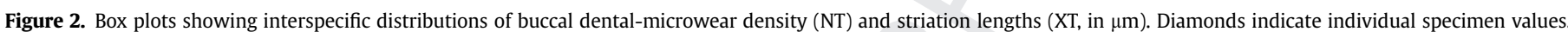

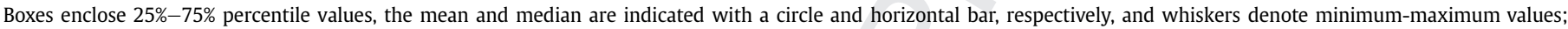
sample sizes are indicated besides the taxon name.

Table 4

Pearsons' product-moment correlation $(r)$ between the 2 first canonical variates (CV1-2) on buccal dental-microwear patterns for the taxa considered.

\begin{tabular}{lcc}
\hline Canonical variate $(\mathbf{C V})^{\mathrm{a}}$ & CV1 & CV2 \\
\hline Eigenvalues & 1.563 & 0.980 \\
\% variance & 51.812 & 32.491 \\
\hline Variables & $\boldsymbol{r}^{a}$ & $\boldsymbol{r}^{a}$ \\
\hline NH & $-0.409^{*}$ & $0.409^{*}$ \\
NV & $0.922^{*}$ & 0.104 \\
NMD & 0.158 & $0.471^{*}$ \\
NDM & $-0.301^{*}$ & $0.762^{*}$ \\
XH & 0.164 & $-0.346^{*}$ \\
XV & 0.165 & $-0.426^{*}$ \\
XMD & $0.325^{*}$ & $-0.320^{*}$ \\
XDM & 0.076 & $-0.330^{*}$ \\
\hline
\end{tabular}

a CVA included 8 taxa (7 extant primate species and the extinct T. oswaldi) and 8 buccal microwear density and length (in $\mu \mathrm{m}$ ) variables (see material and methods section for species and variable description details). Significant correlation ( $r$ Pearson) at $\mathrm{p}<0.01\left(^{*}\right)$.

mouth while food is being chewed. CV2 was also significantly correlated with $\mathrm{NH}(r=0.409 ; \mathrm{p}<0.001)$ and NMD $(r=0.471$; $\mathrm{p}<0.001)$ and negatively with the striation lengths by orientation, including XH $(r=-0.346$; $\mathrm{p}<0.001)$ XV $(r=-0.426$; $\mathrm{p}<0.001)$, $\mathrm{XMD}(r=-0.320 ; \mathrm{p}=0.001)$, and $\mathrm{XDM}(r=-0.330 ; \mathrm{p}=0.001)$. The second canonical variate (CV2) was positively correlated with all the density variables and negatively with all the striation length variables, separating Colobus and Papio from the rest of primates. In the canonical plot of CV1 versus CV2 (Fig. 3), the generalist feeder $P$. anubis, the folivorous Colobus, and the granivorous $T$. gelada showed negative CV2 values, whereas the mainly frugivorous Chlorocebus and Cercopithecus and the hard-shell fruit eaters Mandrillus and Cercocebus showed positive values for CV2, indicative of higher overall densities of striations. The T. oswaldi specimens clearly differed from the extant Cercopithecid primates studied (see Table 1) and greatly overlapped with Mandrillus and Cercocebus primates in the canonical plot (Fig. 3). This position is because of their low density of vertical striations ( $\mathrm{NV}=44$, the second smallest), their large density of oblique striations (NDM $=67.67, \mathrm{NMD}=136.67$; the largest ones), and their short average striation length (XT $=72.70$, the smallest values). In fact, $T$. oswaldi showed the highest overall mean and median striation density (NT) and the lowest mean and median striation length (XT) of all the Cercopithecoidea species analyzed (Fig. 2). Overall, the CVA showed closer affinities of T. oswaldi and Cercocebus sp. and M. sphinx than to the other taxa considered, which suggests consumption of a broad base diet with high mechanical demands, likely relying on hard-shell fruits and seeds.

\section{Discussion}

The buccal dental microwear pattern of T. oswaldi from Cueva Victoria is characterized by heavily abraded buccal surfaces with a high number of enamel striations compared with the rest of the Cercopithecoidea taxa analyzed in the present study. The density of the buccal striations of the fossil Theropithecus specimens from

Table 5

Assignment test results based on the canonical variates analysis (CAV).

\begin{tabular}{|c|c|c|c|c|c|c|c|c|c|c|c|}
\hline & & Cer & $\mathrm{Cm}$ & $C p$ & $\mathrm{Col}$ & Ms & $\mathrm{Pa}$ & $\mathrm{Tg}$ & To & Sample size & $\%$ Correct assignment \\
\hline Cercocebus sp. & Cer & 5 & 1 & 0 & 1 & 0 & 1 & 0 & 1 & 9 & $55.56 \%$ \\
\hline Cercopithecus mitis & $\mathrm{Cm}$ & 0 & 7 & 0 & 0 & 1 & 2 & 0 & 0 & 10 & $70.00 \%$ \\
\hline Chlorocebus pygerythrus & $C p$ & 1 & 2 & 8 & 0 & 1 & 1 & 2 & 0 & 15 & $53.33 \%$ \\
\hline Colobus sp. & $\mathrm{Col}$ & 2 & 0 & 0 & 18 & 1 & 0 & 0 & 0 & 21 & $85.71 \%$ \\
\hline Mandrillus sphinx & Ms & 1 & 0 & 0 & 0 & 6 & 0 & 0 & 0 & 7 & $85.71 \%$ \\
\hline Papio anubis & $\mathrm{Pa}$ & 1 & 2 & 1 & 0 & 0 & 19 & 2 & 2 & 27 & $70.37 \%$ \\
\hline Theropithecus gelada & $\mathrm{Tg}$ & 0 & 1 & 0 & 2 & 0 & 1 & 4 & 0 & 8 & $50.00 \%$ \\
\hline Theropithecus oswaldi & To & 0 & 0 & 0 & 0 & 1 & 0 & 0 & 2 & 3 & $66.67 \%$ \\
\hline Total & & 10 & 13 & 9 & 21 & 10 & 24 & 8 & 5 & 100 & $69.00 \%$ \\
\hline
\end{tabular}


Table 6

Assignment test results based on the canonical variates analysis (CVA) after cross-validation.

\begin{tabular}{|c|c|c|c|c|c|c|c|c|c|c|c|}
\hline & & Cer & $\mathrm{Cm}$ & $C p$ & Col & Ms & $\mathrm{Pa}$ & $\mathrm{Tg}$ & To & Sample size & $\%$ Correct assignment \\
\hline Cercocebus sp. & $\mathrm{Cer}$ & 4 & 1 & 1 & 1 & 0 & 1 & 0 & 1 & 9 & $44.44 \%$ \\
\hline Cercopithecus mitis & $\mathrm{Cm}$ & 0 & 4 & 2 & 0 & 1 & 3 & 0 & 0 & 10 & $40.00 \%$ \\
\hline Chlorocebus pygerythrus & $C p$ & 1 & 2 & 6 & 1 & 1 & 2 & 2 & 0 & 15 & $40.00 \%$ \\
\hline Colobus sp. & Col & 2 & 0 & 0 & 17 & 1 & 1 & 0 & 0 & 21 & $80.95 \%$ \\
\hline Mandrillus sphinx & Ms & 2 & 0 & 1 & 0 & 4 & 0 & 0 & 0 & 7 & $57.14 \%$ \\
\hline Papio anubis & $\mathrm{Pa}$ & 1 & 3 & 1 & 0 & 0 & 17 & 3 & 2 & 27 & $62.96 \%$ \\
\hline Theropithecus gelada & $\mathrm{Tg}$ & 1 & 1 & 1 & 1 & 0 & 1 & 3 & 0 & 8 & $37.50 \%$ \\
\hline Theropithecus oswaldi & To & 1 & 0 & 0 & 0 & 1 & 0 & 0 & 1 & 3 & $33.33 \%$ \\
\hline Total & & 12 & 11 & 12 & 20 & 8 & 25 & 8 & 4 & 100 & $56.00 \%$ \\
\hline
\end{tabular}

Cueva Victoria differs from that shown by the extant $T$. gelada and resembles those of African Cercocebus or Mandrillus. Our results indicate that the diet of $T$. oswaldi from Cueva Victoria would have differed from those of Colobus, a general folivore, and Papio, a savanna-dwelling omnivore. In contrast, the $T$. oswaldi diet from Cueva Victoria would have resembled that of Mandrillus and Cercocebus, which have abrasive diets, with mechanically challenging foodstuffs, such as hard-shell fruits and seeds, specifically during the dry season (Lahm, 1986; Wieczkowski, 2003). Fruits are the major all-year-round food item of Mandrillus and an important allseason resource for Cercocebus. However, consumption of extrinsic grit particles, incorporated to their diet from seeds and grasses, could account for the striation densities observed as both primates forage on the ground too. The abraded buccal surfaces observed in T. oswaldi might as well reflect consumption of these abrasives incorporated in their diet during food gathering. Some anatomical adaptations of $T$. oswaldi from African sites suggest a terrestrial (Jolly, 1972; Krentz, 1993) habitat, similar to Papio species. However, some studies have assigned a degree of arboreality to $T$. oswaldi
(Eaton, Jolly, 1972; Elton, 2002). As the habitat preference of this 07 large-bodied primate has not been resolved in African sites, it is difficult to conclude which was the ecological niche occupied and therefore, the influence of external grit in its diet.

Theropithecus oswaldi had a wide geographic distribution throughout Eurasia, although the fossil specimens found out of Africa are scarce and dispersed. The presence of Theropithecus in Cueva Victoria suggests a dispersal from Africa into Europe before 1.0 Ma (Gibert et al., 2003, 2016; Ferràndez-Cañadell et al., 2014). Several climatic turnover events have been postulated from 2.5 to 0.9 Ma in Europe (Sardella et al., 1998; Agustí and Antón, 2002). The advance of ice sheets caused a shift toward cooler temperatures and the reduction of Pliocene forests in Europe, with the consequent transition from humid forest fauna to temperate grass and woodland faunas (Sardella et al., 1998). The paleocological reconstruction at Cueva Victoria describes a Mediterranean ecosystem around 1.0 Ma, with open habitats and sparsely closed forests close to water streams. The high densities of striations observed in the T. oswaldi specimens from Cueva Victoria is consistent with the
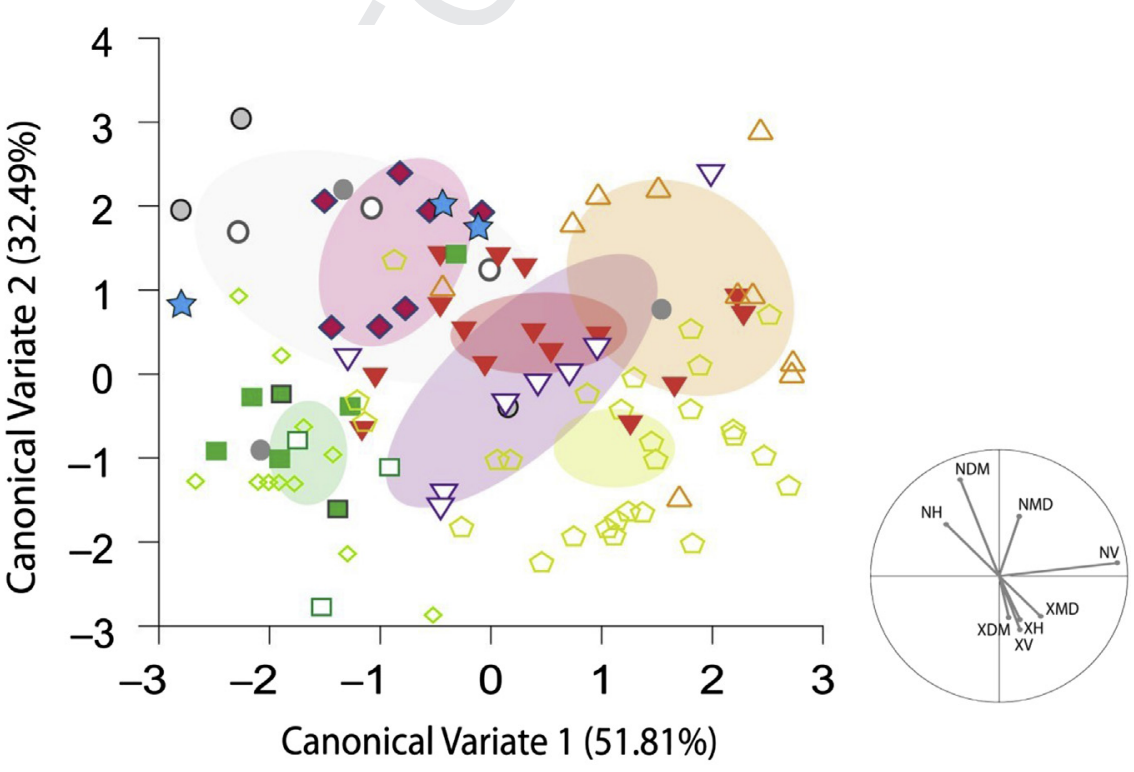

Figure 3. Scatter plot of the first 2 canonical variates (CV1 versus CV2) that account for $84.304 \%$ of total buccal-microwear pattern variance. The ellipses represent $95 \%$ confidence intervals of the centroids between extant taxa. The labeled rays show the unrotated loadings of the microwear variables onto CV1 and CV2. Note that the interspecific variation in buccal-microwear reflects differences in buccal microwear patterns caused by abrasiveness of feeding habits. 
consumption of abrasive, tough, or brittle food items, which could be obtained in both open and forested habitats.

Owing to the small sample size available from Cueva Victoria, it is difficult to assure that $T$. oswaldi ate mechanically challenging items as seasonal fallback foods in open or forested areas of Mediterranean ecosystems. However, the differences in buccal microwear pattern observed when compared with Cercopithecus and Chlorocebus suggest that the diet of these T. oswaldi would have been more abrasive than those of more frugivorous primates which incorporate over $50 \%$ of fruit in their diets. The similar buccal microwear patterns of $T$. oswaldi and the baboons suggest that the extinct species did not intensively exploit open habitats, as does Papio anubis when foraging for underground storage organs (Galbany et al., 2014). The differences observed with the Colobus specimens suggest that leaves, mainly from forested areas, would not have been a significant food item in the diet of $T$. oswaldi.

The environmental reconstructions of the African sites bearing Theropithecus fossil specimens are indicative of relatively closed habitats (Reed, 1997), and the postcranial evidence suggests that Theropithecus species may have been able to exploit both arboreal and terrestrial substrates (Elton, 2002). The differences in the total number of striations compared with the extant $T$. gelada indicate that the diet of T. oswaldi from Cueva Victoria would not have been a grass eater specialist, as T. gelada. Moreover, T. oswaldi teeth differ from those of $T$. gelada in their considerably greater size (FerràndezCañadell et al., 2014). The similarities of the buccal microwear pattern of T. oswaldi to Cercocebus and Mandrillus, rather than to T. gelada, support the hypothesis that the fossil species from Cueva Victoria would have had a broader dietary regime than the extant graminivorous $T$. gelada, as a requirement to deal with the climatic events affecting Eurasia at around 1.0 Ma. Therefore, the buccal microwear pattern of T. oswaldi from Cueva Victoria is consistent with a diet based on hard, brittle plant foods-such as hard-shell fruits and seeds-combined with a soft frugivorous diet resembling the diets of Mandrillus and Cercocebus. Cercocebus is a terrestrial forager that habitually consumes hard shell nuts (as Sacoglottis) year-round, with seasonal fluctuations (Daegling et al., 2011). The protective exocarp casing of nuts and fruits requires strong bite forces for food processing, which increases the risk of tooth fracture. The cranio-dental adaptations and the specializations of the temporomandibular joint described for T. oswaldi (Jablonski, 1993b) are consistent with the heavy dietary loads derived from the analysis of the buccal dental microwear pattern of the fossil remains of $T$. oswaldi from Cueva Victoria.

\section{Conclusions}

The high abraded buccal microwear pattern of $T$. oswaldi from Cueva Victoria and the similarities observed with the extant Cercocebus and Mandrillus specimens studied are consistent with the hypothesis that $T$. oswaldi exploited hard-shell and mechanically challenging food items in Mediterranean habitats. T. oswaldi would have had a dietary behavior significantly distinct to that of the extant $T$. gelada, which shows a derived dietary specialization in a Q8 recent, anthropogenic conditioned ecosystem.

\section{Acknowledgments}

This work was supported by Ministerio de Investigación, Desarrollo e Innovación, Spanish Project (CGL2014-52611-C2-1-P, http://www.idi.mineco.gob.es/), Fundación Obra Social La Caixa (https://obrasociallacaixa.org) as well as by the grants SGR2009884 Group of Study on the Evolution of Hominins and other Primates, and SGR2017-824 Geologia Sedimentària by Generalitat de Catalunya. Scanning electron micrographs were obtained at the
Centres Científics i Tecnològics of the Universitat de Barcelona and Serveis Tècnics d'Investigació of the Universitat d'Alacant.

\section{References}

Alberdi, M.T., Piñero, P., 2015. Estudio de los caballos del yacimiento de Cueva Victoria, Pleistoceno Inferior (Murcia). Mastia 11-13, 325-358.

Albert, R.M., Bamford, M.K., Stanistreet, I., Stollhofen, H., Rivera-Rondón, C., Rodríguez-Cintas, A., 2015. Vegetation landscape at DK locality, Olduvai Gorge, Tanzania. Palaeogeogr. Palaeoclimatol. Palaeoecol. 426, 34-45.

Alemseged, Z., Geraads, D., 1998. Theropithecus atlanticus (Thomas, 1884) (Primates: Cercopithecidae) from the late Pliocene of Ahl al Oughlam, Casablanca, Morocco. J. Hum. Evol. 34, 609-621.

Agustí, J., Antón, M., 2002. Mammoths, Sabretooths and Hominids. Columbia University Press, New York.

Anton, M., Galobart, A., Turner, A., 2005. Co-existence of scimitar-toothed cats, lions and hominids in the European Pleistocene. Implications of the post-cranial anatomy of Homotherium altidens (Owen) for comparative palaeoecology. Quat. Sci. Rev. 24, 1287-1301.

Belay, G., Mori, A., 2006. Intraspecific phylogeographic mitochondrial DNA (D-loop) variation of Gelada baboon, Theropithecus gelada, in Ethiopia. Biochem. Systemat. Ecol. 34, 554-561.

Belmaker, M., 2010. The presence of a large cercopithecine (cf. Theropithecus sp.) in the 'Ubeidiya formation (Early Pleistocene, Israel). J. Hum. Evol. 58, 79-89.

Benefit, B.R., McCrossin, M.L., 1990. Diet, species diversity and distribution of African fossil baboons. Kroeber Anthropol. Soc. Pap. 71, 77-93.

Bonnefille, R., 2010. Cenozoic vegetation, climate changes and hominid evolution in tropical Africa. Global Planet. Change 72, 390-411.

Brugal, J.P., Croitor, R., 2007. Evolution, ecology and biochronology of herbivore associations in Europe during the last 3 million years. Quaternaire 19, 1-23.

Carrión, J.S., Scott, L., Arribas, A., Fuentes, N., Gil-Romera, G., Montoya, E., 2007. Pleistocene landscapes in central Iberia inferred from pollen analysis of hyena coprolites. J. Quat. Sci. 22, 191-202.

Cerling, T.E., Chritz, K.L., Jablonski, N.G., Leakey, M.G., Manthi, F.K., 2013. Diet of Theropithecus from 4 to $1 \mathrm{Ma}$ in Kenya. Proc. Natl. Acad. Sci. U.S.A. 110, 10507-10512.

Ciochon, R.L., 1993. Evolution of the Cercopithecoid forelimb: phylogenetic and functional implications from morphological analyses. Geological Sciences, vol. 138. University of California Press, Berkeley.

Codron, D., Luyt, J., Lee-Thorp, J.A., Sponheimer, M., De Ruiter, D., Codron, J., 2005 Utilization of savanna-based resources by Plio-Pleistocene baboons. South Afr. J. Sci. 101, 245-248.

Daegling, D.J., McGraw, S., Ungar, P.S., Pampush, J.D., Vick, A.E., Anderson, B., 2011 Hard-object feeding in sooty mangabeys (Cercocebus atys) and interpretation of early hominin feeding ecology. PLoS One 6, e23095.

Dasilva, G.L., 1994. Diet of Colobus polykomos on Tiwai Island: selection of food in relation to its seasonal abundance and nutritional quality. Int. J. Primatol. 15, 655-680.

Delson, E., 1993. Theropithecus fossils from Africa and India and the taxonomy of the genus. In: Jablonski, N.G. (Ed.), Theropithecus: The Rise and Fall of a Primate Genus. Cambridge University Press, Cambridge, pp. 157-190.

Delson, E., Eck, G.G., Leakey, M.G., Jablonski, N.G., 1993. A partial catalogue of fossil remains of Theropithecus. In: Jablonski, N.G. (Ed.), Theropithecus: The Rise and Fall of a Primate Genus. Cambridge University Press, Cambridge, pp. 499-525.

Dunbar, R.I.M., Bose, U., 1991. Adaptation to grass-eating in gelada baboons. Primates 32, 1-7.

Elton, S., 2002. A reappraisal of the locomotion and habitat preference of Ther opithecus oswaldi. Folia Primatol. 73, 252-280.

Elton, S., 2007. Environmental correlates of the cercopithecoid radiations. Folia Primatol. 78, 344-364.

El-Zaatari, S., Grine, F.E., Teaford, M.F., Smith, H.F., 2005. Molar microwear and dietary reconstructions of fossil Cercopithecoidea from the Plio-Pleistocene deposits of South Africa. J. Hum. Evol. 49, 180-205.

Estebaranz, F., Martínez, L.M., Galbany, J., Turbón, D., Pérez-Pérez, A., 2009. Testing hypotheses of dietary reconstruction from buccal dental microwear in Australopithecus afarensis. J. Hum. Evol. 57, 739-750.

Estebaranz, F., Galbany, J., Martínez, L.M., Turbón, D., Pérez-Pérez, A., 2012. Buccal dental microwear analyses support greater specialization in consumption of hard foodstuffs for Australopithecus anamensis. J. Anthropol. Sci. 90, 63-185.

Fashing, P.J., Nguyen, N., Fashing, N.J., 2010. Behaviour of geladas and other endemic wildlife during a desert locust outbreak at Guassa, Ethiopia: ecological and conservation implications. Primates 51, 193-197.

Fashing, P.J., Nguyen, N., Venkataraman, V.V., Kerby, J.T., 2014. Gelada feeding ecology in an intact ecosystem at Guassa, Ethiopia: variability over time and implications for theropith and hominin dietary evolution. Am. J. Phys. Anthropol. 155, 1-16.

Ferràndez-Cañadell, C., 2015a. Contexto sedimentario y tafonomía de Cueva Victoria. Mastia 11-13, 139-162.

Ferràndez-Cañadell, C., 2015b. Grupos pendientes de estudio o revisión. Mastia $11-13,453-461$.

Ferràndez-Cañadell, C., Gibert, L., 2015. Introducción. Cueva Victoria, un yacimiento de vertebrados del Pleistoceno Inferior. Mastia 11-13, 17-45. 
Ferràndez-Cañadell, C., Ribot, F., Gibert, L., 2014. New fossil teeth of Theropithecus oswaldi (Cercopithecoidea) from the Early Pleistocene at Cueva Victoria. J. Hum. Evol. 74, 55-66. SESpain.

Fleagle, J.G., McGraw, W.S., 2002. Skeletal and dental morphology of African papionins: unmasking a cryptic clade. J. Hum. Evol. 42, 267-292.

Frost, S.R., Jablonski, N.G., Haile-Selassie, Y., 2014. Early Pliocene Cercopithecidae from Woranso-Mille (Central Afar, Ethiopia) and the origins of the Theropithecus oswaldi lineage. J. Hum. Evol. 76, 39-53.

Galbany, J., Moyà-Solà, S., Pérez-Pérez, A., 2005a. Dental microwear variability on buccal tooth enamel surfaces of extant Catarrhini and the Miocene fossil Dryopithecus laietanus (Hominoidea). Folia Primatol. 76, 325-341.

Galbany, J., Martínez, L.M., López-Amor, H.M., Espurz, V., Hiraldo, O., Romero, A., De Juan, J., Pérez-Pérez, A. 2005b. Error rates in buccal-dental microwear quantification using scanning electron microscopy. Scanning 27, 23-29.

Galbany, J., Estebaranz, F., Martínez, L.M., Romero, A., De Juan, J., Turbón, D., PérezPérez, A., 2006. Comparative analysis of dental enamel polyvinylsiloxane impression and polyurethane casting methods for SEM research. Microsc. Res. Tech. 69, 246-252.

Galbany, J., Romero, A., Mayo-Alesón, M., Itsoma, F., Gamarra, B., Pérez-Pérez, A., 2014. Age-related tooth wear differs between forest and savanna primates. Plos One 9, e94938.

Gibert, L., Ferràndez-Cañadell, C., 2015. Geología y paleontología de Cueva Victoria. Mastia 11-13, 478

Gibert, J., Ferràndez, C., Pérez-Cuadrado, J.L., Martínez, B., 1992. Cueva Victoria: Cubil de carroñeros. In: Gibert, J. (Ed.), Presencia humana en el Pleistoceno Inferior de Granada y Murcia. Publicaciones del Museo de Prehistoria de Orce Granada, pp. 133-142.

Gibert, J., Ribot, F., Gibert, L., Leakey, M., Arribas, A., Martínez, B., 1995. Presence of the cercopithecid genus Theropithecus in Cueva Victoria (Murcia, Spain). J. Hum Evol. 28, 487-493.

Gibert, J., Gibert, L., Iglesias, A., 2003. The Gibraltar Strait: A Pleistocene door of Europe? Hum. Evol. 18, 147-160.

Gibert, J., Gibert, L., Ferràndez-Cañadell, C., Ribot, F., Iglesias, A., Gibert, P., 2006 Cueva Victoria: Geología, paleontología, restos humanos y edades. Memorias de Arqueología, Región de Murcia 14, 37-62.

Gibert, L., Scott, G.R., Scholz, D., Budsky, A., Ferràndez, C., Ribot, R., Martin, R.A Lería, M., 2016. Chronology for the Cueva Victoria fossil site (SE Spain): Evidence for Early Pleistocene Afro-Iberian dispersals. J. Hum. Evol. 90, 18-197.

Gügel, I.L., Grupe, G., Kunzelmann, K.H., 2001. Simulation of dental microwear: characteristic traces by opal phytoliths give clues to ancient human dietary behavior. Am. J. Phys. Anthropol. 114, 124-138.

Gupta, V.L., Sahni, A., 1981. Theropithecus delsoni, a new cercopithecine species from the Upper Siwaliks of India. Bull. Indian Geol. Assoc. 14, 69-71.

Homewood, K.M., 1978. Feeding strategy of the Tana mangabey (Cercocebus galeritus galeritus) (Mammalia: Primates). J. Zool. 186, 375-391.

Hoshino, J., 1985. Feeding ecology of mandrills (Mandillus sphinx) in Campo Animal Reserve, Cameroon. Primates 26, 248-273.

Hughes, J.K., Elton, S., O'Regan, H.J., 2008. Theropithecus and 'Out of Africa' dispersal in the Plio-Pleistocene. J. Hum. Evol. 54, 43-77.

Iwamoto, T., Dunbar, R.I.M., 1983. Thermoregulation, habitat quality and the behavioural ecology of gelada baboons. J. Anim. Ecol. 52, 357-366.

Jablonski, N.G., 1993a. Quaternary environments and the evolution of primates in East Asia, with notes on two new specimens of fossil Cercopithecidae from China. Folia Primatol. 60, 118-132.

Jablonski, N.G., 1993b. The phylogeny of Theropithecus. In: Jablonski, N.G. (Ed.), Theropithecus: The Rise and Fall of a Primate Genus. Cambridge University Press, Cambridge, pp. 209-224.

Jablonski, N.G., 1994. Convergent evolution in the dentitions of grazing macropodine marsupials and the grass-eating cercopithecine primate Theropithecus gelada. J. Roy. Soc. West Aust. 77, 37-43.

Jablonski, N.G., 2002. Fossil Old World monkeys: The late Neogene radiation. In: Hartwig, W.C. (Ed.), The Primate Fossil Record. Cambridge University Press, Cambridge, pp. 255-299.

Jablonski, N.G., Leakey, M.G., Antón, M., 2008. Systematic paleontology of the cercopithecines. Koobi Fora Res. Proj. 6, 103-300.

Jolly, C.J., 1972. The classification and natural history of Theropithecus (Simopithecus) (Andrews, 1916), baboons of the African Plio-Pleistocene. Bull. Br. Mus. (Nat. Hist.) Geol. 22, 1-123.

Kay, R.F., 1981. The nut-crackers-a new theory of the adaptations of the Ramapithecinae. Am. J. Phys. Anthropol. 55, 141-151.

Krentz, H.B., 1993. Postcranial anatomy of extant and extinct species of Theropithecus. In: Jablonski, N.G. (Ed.), Theropithecus: The Rise and Fall of a Primate Genus. Cambridge University Press, Cambridge, pp. 383-422.

Lahm, S.A., 1986. Diet and habitat preferences of Mandrillus sphinx in Gabon: implications of foraging strategy. Am. J. Primatol. 11, 9-26.

Lalueza-Fox, C., Perez-Perez, A., Juan, J., 1994. Dietary information through the examination of plant phytoliths on the enamel surface of human dentition. J. Archaeol. Sci. 21, 29-34.

Leakey, M.G., 1993. Evolution of Theropithecus in the Turkana basin. In: Jablonski, N.G. (Ed.), Theropithecus: The Rise and Fall of a Primate Genus. Cambridge University Press, Cambridge, pp. 85-123.

Lee, P.C., 1984. Ecological constraints of the social development of the vervet monkeys. Behaviour 91, 245-262.
Lee-Thorp, J.A., van der Merwe, N.J., 1993. Stable carbon isotope studies of Swartkrans fossils. In: Brain, C.K. (Ed.), Swartkrans: A Cave's Chronicle of Early Man, vol. 8. Transvaal Museum Monographs, pp. 251-256.

Lee-Thorp, J.A., van der Merwe, N.J., Brain, C.K., 1989. Isotopic evidence for dietary differences between two extinct baboon species from Swartkrans. J. Hum. Evol. $18,183-189$.

Levin, N.E., Haile-Selassie, Y., Frost, S.R., Saylor, B.Z., 2015. Dietary change among hominins and cercopithecids in Ethiopia during the early Pliocene. Proc. Natl. Acad. Sci. U.S.A. 112, 12304-12309.

Lucas, P., Constantino, P., Wood, B., Lawn, B., 2008. Dental enamel as a dietary indicator in mammals. Bioessays 30, 374-385.

Lucas, P.W., Omar, R., Al-Fadhalah, K., Almusallam, A.S., Henry, A.G., Michael, S. Arockia, T., Watzeke, J., Strait, D.S., Atkins, A.G., 2013. Mechanisms and causes of wear in tooth enamel: implications for hominin diets. J. R. Soc. Interface 10, 20120923.

Mau, M., Südekum, K.H., Johann, A., Sliwa, A., Kaiser, T.M., 2009. Saliva of the graminivorous Theropithecus gelada lacks proline-rich proteins and tanninbinding capacity. Am. J. Primatol. 71, 663-669.

Madurell-Malapeira, J., Ros-Montoya, S., Espigares, M.P., Alba, D.M., AurellGarrido, J., 2014. Villafranchian large mammals from the Iberian Peninsula: paleobiogeography, paleoecology and dispersal events. J. Iber. Geol. 40, 167-178.

Magill, C.R., Ashley, G.M., Domínguez-Rodrigo, M., Freeman, K.H., 2016. Dietary options and behavior suggested by plant biomarker evidence in an early human habitat. Proc. Natl. Acad. Sci. U.S.A. 113, 2874-2879.

Martínez, L.M., Estebaranz-Sánchez, F., Galbany, J., Pérez-Pérez, A., 2016. Testing dietary hypotheses of East African hominines using buccal dental microwear data. PloS One 11, e0165447.

McGraw, W.S., Pampush, J.D., Daegling, D.J., 2012. Brief communication: Enamel thickness and durophagy in mangabeys revisited. Am. J. Phys. Anthropol. 147, 326-333.

McGraw, W.S., van Casteren, A., Kane, E., Geissler, E., Burrows, B., Daegling, D.J., 2016. Feeding and oral processing behaviors of two colobine monkeys in Tai Forest, Ivory Coast. J. Hum. Evol. 98, 90-102.

Mitani, M., 1989. Cercocebus torquatus: adaptive feeding and ranging behaviors related to seasonal fluctuations of food resources in the tropical rain forest of South-Western Cameroon. Primates 30, 307-323.

Moges, E., Balakrishnan, M., 2014. Nutritional composition of food plants of geladas (Theropithecus gelada) in Guassa Community Protected Area, Ethiopia. J. Biol. Agric. Healthc. 4, 38-45.

Oates, J.F., Davies, A.G., 1994. What are the colobines? In: Davies, A.G., Oates, J.F. (Eds.), Colobine Monkeys: Their Ecology, Behaviour and Evolution. Cambridge University Press, Cambridge, pp. 1-10.

Palmqvist, P., Gröcke, D.R., Arribas, A., Fariña, R.A., 2003. Paleoecological reconstruction of a lower Pleistocene large mammal community using biogeochemical $(\delta 13 \mathrm{C}, \delta 15 \mathrm{~N}, \delta 180, \mathrm{Sr}: \mathrm{Zn})$ and ecomorphological approaches. Paleobiology 29, 205-229.

Palmqvist, P., Martínez, B., Espigares, M.P., Pérez Claros, J.A., Ros, S., Torregrosa, V., Figueirido, B., De Renzi, M., 2011. Análisis tafonómico y paleocológico de la fauna de grandes herbívoros conservada en los yacimientos del sector OrceVenta-Micena (Cuenca de Guadix-Baza) y su interés con vistas a establecer el contexto faunístico de la primera dispersión humana a Europa. In: Toro, I., Martínez, B., Agustí, J. (Eds.), Ocupaciones Humanas en el Pleistoceno Inferior y Medio de la Cuenca de Guadix-Baza. Junta de Andalucía, Consejería de Cultura, pp. 341-389.

Patnaik, R., Nanda, A.C., 2010. Early Pleistocene mammalian faunas of India and evidence of connections with other parts of the world. In: Fleagle, J.G., Shea, J.J., Grine, F.E., Baden, A.L., Leakey, R.E. (Eds.), Out of Africa I. The First Hominin Colonization of Eurasia. Springer, Netherlands, pp. 129-143.

Patnaik, R., Cerling, T.E., Uno, K.T., Fleagle, J.G., 2014. Diet and habitat of Siwalik primates Indopithecus, Sivaladapis and Theropithecus. Ann. Zool. Fenn. 51, 123-142.

Pazol, K., Cords, M., 2005. Seasonal variation in feeding behavior, competition and female social relationships in a forest dwelling guenon, the blue monkey (Cercopithecus mitis stuhlmanni), in the Kakamega Forest, Kenya. Behav. Ecol. Sociobiol. 58, 566-577.

Pérez-Pérez, A., Espurz, V., Bermúdez de Castro, J.M., de Lumley, M.A., Turbón, D., 2003. Non-occlusal dental microwear variability in a sample of Middle and Late Pleistocene human populations from Europe and the Near East. J. Hum. Evol. 44, 497-513.

Pickford, M., 1993. Climatic change, biogeography, and Theropithecus. In: Jablonski, N.G. (Ed.), Theropithecus: The Rise and Fall of a Primate Genus. Cambridge University Press, Cambridge, pp. 227-243.

Reed, K.E., 1997. Early hominid evolution and ecological change through the African Plio-Pleistocene. J. Hum. Evol. 32, 289-322.

Romero, A., Galbany, J., De Juan, J., Pérez-Pérez, A., 2012. Short and long-term in vivo human buccal dental-microwear turnover. Am. J. Phys. Anthropol. 148, 467-472.

Romero, A., Ramírez-Rozzi, F.V., De Juan, J., Pérez-Pérez, A., 2013. Diet-related buccal dental microwear patterns in Central African pygmy foragers and Bantuspeaking farmer and pastoralist populations. PLoS One8, e84804.

Sardella, R., Caloi, L., Di Stefano, G., Palombo, M.R., Petronio, C., Abbazzi, L., Azzarli, A., Ficcarelli, G., Mazza, P., Mezzabotta, C., Rook, L., Torre, D., Argenti, P., Capasso Barbato, L., Kotsakis, T., Gliozzi, E., Masini, F., Sala, B., 1998. Mammal 
YJHEV102736_proof — 28 January 2020

$12 / 12$

12

L.M. Martinez et al. / Journal of Human Evolution $x x x(x x x x) x x x$

faunal turnover in Italy from the Middle Pliocene to the Holocene. Meded. Ned. Inst. Toegepaste Geowetenschappen TNO 60, 499-511.

Sevilla, P., 2015. The Lower Pleistocene bats from Cueva Victoria. Bastia 11-13, 239-251.

Shapiro, A.E., Venkataraman, V.V., Nguyen, N., Fashing, P.J., 2016. Dietary ecology of fossil Theropithecus: Inferences from dental microwear textures of extant geladas from ecologically diverse sites. J. Hum. Evol. 99, 1-9.

Singleton, M., 2005. Functional shape variation in the cercopithecine masticatory complex. In: Slice, D.E. (Ed.), Modern Morphometrics in Physical Anthropology. Developments in Primatology: Progress and Prospects. Springer, Boston, pp. 319-348.

Souron, A., 2018. Morphology, diet, and stable carbon isotopes: on the diet of Theropithecus and some limits of uniformitarianism in paleoecology. Am. J. Phys. Anthropol. 166, 261-267.

Swedell, L., 2011. African Papionins: diversity of social organization and ecological flexibility. In: Campbell, C.J., Fuentes, A., MacKinnon, K.C., Bearder, S.K., Stumpf, R.M. (Eds.), Primates in Perspective. Oxford University Press, New York, pp. $241-277$.

Teaford, M.F., 1993. Dental microwear and diet in extant and extinct Theropithecus: preliminary analyses. In: Jablonski, N.G. (Ed.), Theropithecus: The Rise and Fall of a Primate Genus. Cambridge University Press, Cambridge, pp. 331-349.

Teaford, M.F., Walker, A., 1984. Quantitative differences in dental microwear between primate species with different diets and a comment on the presumed diet of Sivapithecus. Am. J. Phys. Anthropol. 64, 191-200.

Van Der Merwe, N.J., Thackeray, J.F., Lee-Thorp, J.A., Luyt, J., 2003. The carbon isotope ecology and diet of Australopithecus africans at Sterkfontein, South Africa. J. Hum. Evil. 44, 581-597.

Venkataraman, V.V., Glowacka, H., Fritz, J., Clauses, M., Seyoum, C., Nguyen, N., Fashing, P.J., 2014. Effects of dietary fracture toughness and dental wear on chewing efficiency in geladas (Theropithecus gelada). Am. J. Phys. Anthropol. 155, 17-32.

Whiten, A., Byrne, R.W., Barton, R.A., Waterman, P.G., Henzi, S.P., 1991. Dietary and foraging strategies of baboons. Phil. Trans. Roy. Soc. Lond. 334, 187-197.

Wieczkowski, J., 2003. Aspects of the ecological flexibility of the Tana mangabey (Cercocebus galeritus) in its fragmented habitat, Tana River, Kenya. Ph.D. Dissertation. University of Georgia.

Wieczkowski, J., 2009. Puncture and crushing resistance scores of Tana river mangabey (Cercocebus galeritus) diet items. Am. J. Phys. Anthropol. 140, 572-577.

Wieczkowski, J., Kinnaird, M., 2008. Shifting forest composition and primate diets: a 13- year comparison of the Tana River mangabey and its habitat. Am. J. Frimatol. 70, 339-348.

Willems, E.P., Hill, R.A., 2009. A critical assessment of two species distribution models: a case study of the vervet monkey (Cercopithecus aethiops). J. Biogeogr. 36, 2300-2312.

Woldegeorgis, C., Bekele, A., 2015. Diet and feeding behaviour of geladas (Teropithecus gelada) at the Gish area of the Simien Mountains National Park, Ethiopia. Global J. Biol. Agric. Health Sci. 4, 178-184.

Wynn, J.G., Reed, K.E., Sponheimer, M., Kimbel, W.H., Alemseged, Z., Bedaso, Z.K., Campisano, C.J., 2016. Dietary flexibility of Australopithecus afarensis in the face of paleoecological change during the middle Pliocene: Faunal evidence from Hadar, Ethiopia. J. Hum. Evil. 99, 93-106.

Xia, J., Than, Z.R., Ha, L., Chen, L., Zhou, Z., Qian, L., Ungar, P.S., 2017. Enamel crystallite strength and wear: nanoscale responses of teeth to chewing loads. J. R. Soc. Interface 14, 20170456.

Zewdu, K., Belay, G., Bekele, A., 2013. Population size, group composition and Behavioural ecology of geladas (Theropithecus gelada) and Human-gelada conflit in Wonchit Valley, Ethiopia. Pakistan J. Biol. Sci. 16, 1248-1259.
25

26

27

28

29

30

31

32

33

34

35

36
37

37
38

39

40

41

42

43

44

45

46
47

48

Please cite this article as: Martinez, L.M et al., Buccal dental-microwear and feeding ecology of Early Pleistocene Theropithecus oswald from

Cueva Victoria (Spain), Journal of Human Evolution, https://doi.org/10.1016/j.jhevol.2019.102736 